\title{
SHORT-TERM ELECTRICITY FUTURES PRICES: EVIDENCE ON THE TIME-VARYING RISK PREMIUM*
}

\author{
Julio J. Lucia and Hipòlit Torróo*
}

WP-EC 2008-08

Correspondence to: J. Lucia, Departament of Financial Economics, University of Valencia, Avda. dels Tarongers s/n, 46022, València (Spain); Tel.: +34 963828 369; Fax: +34 963828 370; E-mail: julio.j.lucia@uv.es.

Editor: Instituto Valenciano de Investigaciones Económicas, S.A.

Primera Edición Mayo 2008

Depósito Legal: V-2459-2008

IVIE working papers offer in advance the results of economic research under way in order to encourage a discussion process before sending them to scientific journals for their final publication.

\footnotetext{
* A preliminary version of this paper was included in a longer previous paper that circulated under the title: "Short-term electricity futures prices at Nord Pool: Forecasting power and risk premiums". It was presented at the XIV Congress of the Spanish Finance Association. We thank Alvaro Cartea, the discussant, and other participants for helpful comments and suggestions. We also thank Ángel Pardo for useful suggestions. We are particulary grateful for assistance with data issues that we received from Magnus Thorstensson from Svensk Energi-Swedenergy AB, Jan Fredrik Foyn and Erling Mork from the Statistics and Analysis Department of Nord Pool ASA, Joonas Koski and Markus Huttunen from the Finnish Environment Institute and Per Tore Jensen Lund from the Norwegian Water Resources and Energy Directorate. Financial support from the Ministerio de Educación y Ciencia (Spain) and FEDER research projects CGL2006-06367/CLI and SEJ2006-15401-C04-04/ECON, and Instituto Valenciano de Investigaciones Económicas (Ivie) are gratefully acknowledged. The usual disclaimer applies.

** J. Lucia: University of Valencia. H. Torró: Departament of Financial Economics, University of Valencia.
} 


\title{
SHORT-TERM ELECTRICITY FUTURES PRICES: EVIDENCE ON THE TIME-VARYING RISK PREMIUM
}

\author{
Julio J. Lucia and Hipòlit Torró
}

\begin{abstract}
This paper examines empirically the relationship between electricity spot and futures prices, by analysing a decade of data for a set of short term-to-maturity futures contracts traded in the Nordic Power Exchange, Nord Pool. It is found that, on average, there are significant positive risk premiums in short-term electricity futures prices. The significance and size of the premiums, however, varies seasonally over the year; whereas it is greatest during winter, it is zero in summer. It is also found that time-varying risk premiums are significantly related to unexpectedly low reservoir levels. Furthermore, before the unprecedented supply-shock that hit the Nord Pool market around the end of year 2002, the variation of the risk premiums was related to the variance and the skewness of future spot prices. This result is consistent with the view that risk considerations played a role in the determination of futures prices. Finally, additional evidence provided throughout the paper supports the view that circumstances changed in the Nord Pool market after the shock period.
\end{abstract}

Keywords: risk premium, electricity futures, Nord Pool

JEL Classifications: G13, L94

\section{RESUMEN}

Este trabajo estudia la relación entre los precios de contado y a futuro de la electricidad a través de un análisis empírico realizado sobre los precios a futuro a corto plazo negociados durante una década en el mercado nórdico de electricidad, Nord Pool. Los resultados indican que existen primas de riesgo positivas en media en los contratos de futuro a corto plazo. Sin embargo, la significatividad y tamaño de las primas varia estacionalmente a lo largo del año, siendo las de mayor tamaño durante el invierno y nulas durante el verano. También se encuentra evidencia significativa relativa a la capacidad explicativa de los niveles anormalmente bajos de las reservas hidráulicas sobre la variación temporal de las primas de riesgo. Además, antes del shock de oferta que azotó el mercado Nord Pool a finales del año 2002, la variación de las primas de riesgo estaba relacionada con la varianza y asimetría de los precios futuros de la electricidad. Este resultado es coherente con la visión de que el riesgo se tomaba en consideración en la determinación de los precios a futuro. Finalmente, a lo largo de todo el documento se muestra evidencia adicional a favor de la opinión de que las circunstancias cambiaron en el Nord Pool después del periodo turbulento.

Palabras clave: prima de riesgo, futuros sobre electricidad, Nord Pool 
Since electricity futures contracts started to be traded worldwide during the last decade, the relationship between futures prices and spot electricity prices has attracted the attention of finance academics and market participants alike, because it is important for understanding not only the pricing of electricity futures contracts, but also a variety of important hedging and other related trading issues.

This paper belongs to the line of research that analyses the relationship between electricity spot and futures prices based mainly on risk considerations. In particular, it focuses on what is termed the futures or forward risk premium, which is defined as the futures or forward price minus the expected delivery-date spot price. This paper contributes to elucidate several issues related to the sign and behaviour over time of the futures or forward premium, by providing an empirical analysis of a set of short termto-maturity futures contracts traded in the Nordic Power Exchange, Nord Pool ASA. The Nord Pool is a non-mandatory multinational wholesale electricity market that covers several Nordic European countries. The analysis of this market is particularly relevant for the understanding of electricity markets because this market has a long history of both "spot" (day-ahead) and futures contracting that can be traced back to the early nineties, and it is generally considered to be one of the most well-established and best functioning electricity markets in the world.

Botterud et al. (2002) provided some previous preliminary empirical evidence for the premiums at the Nord Pool market. They studied a sample of futures and forward data that covered six years of weekly observations, for the 1996-2001 period, for contracts with 1, 4, 26 and 52 weeks to delivery, and delivery periods that ranged from one week to one season in length. However, they only analysed the average premiums for the whole sample period. They found evidence of positive average premiums. They also reported that the magnitude and standard deviation of the premiums increase with the length of the holding period. They also tried to informally link the long-term premiums to deviations from usual reservoir levels, by simple visual inspection of a graph. They, however, left several related issues unexplored, which are addressed for the first time in this paper.

We thus make several contributions to the analysis of the futures premiums at the Nord Pool. Firstly, we explore the importance of the time of maturity (i.e. when electricity is deliverable). In particular, we characterize the seasonal behaviour of the premiums. We find that the premiums are the greatest in winter, whereas they are zero during summer. Secondly, we formally explore the links between the risk premium and the basis (futures price minus spot price) through a VAR econometric model with a high 
explicative power. In particular, our empirical results clarify that it is in fact the unusually low reservoir level which has an additional explicative power on the timevarying behaviour of the risk premiums. Thirdly, we examine some testable implications of the equilibrium model by Bessembinder and Lemmon (2002). To the best of our knowledge, this model is the most serious attempt published to date to cast the determination of electricity forward prices into a one-period equilibrium model specifically developed for electricity markets. ${ }^{1}$ We find that the variation of the risk premium is related to the variance and skewness of future spot prices as predicted by the model - for the period before the shock that hit the Nord Pool market around the end of 2002. This result is consistent with agents that determined futures prices based on risk considerations. Finally, diverse evidence provided throughout the paper supports the view of tighter market conditions in the Nordic market after 2002. Prices and volatility increased, and the Bessembinder and Lemmon implications are rejected after the 20022003 turmoil.

From a broader point of view, this paper builds on the body of research devoted to the direct empirical analysis of the electricity forward risk premium based on equilibrium considerations. Several previous papers concentrate on the day-ahead forward premiums: Geman and Vasicek (2001) consider the Western Hub of the Pennsylvania-New Jersey-Maryland (PJM) market; Longstaff and Wang (2004) analyse the forward premiums in the 24 day-ahead hourly prices traded daily at the PJM electricity market, and Karakatsani and Bunn (2005) consider an intra-daily data set from the British electricity market after the reforms introduced in March 2001 (NETA). Other papers, on the contrary, analyse the premiums for contracts with longer time-tomaturity periods: Bessembinder and Lemmon (2002), for instance, examine one-monthahead power forward contracts (for delivery each on-peak hour during the delivery month) from the PJM and the California Power Exchange (CALPX) markets.

\footnotetext{
1 The general equilibrium model by Bessembinder and Lemmon (2002) has received special attention from previous researchers. The model assumes that prices are determined by industry participants (including producers as well as retailers), and that power companies are concerned with both the mean and the variance of their profits. Along with other interesting results, the model provides equilibrium forward power prices in a closed form, with testable implications concerning the forward premium. In particular, it is shown that the forward risk premium is negatively related to the variance of spot power prices and positively related to the skewness of spot prices. It is also shown that the equilibrium premium in forward power prices is likely to vary in sign and magnitude on a seasonal basis (due to seasonal changes in the probability distribution of spot electricity prices).
} 
Overall, the empirical findings of these papers suggest that the size and sign of the forward premium crucially depends on the time of delivery. Specifically, it is positive and large for those contracts with delivery during demand peak periods (at an hourly as well as at a seasonal level). Additionally, the results seem to be at least broadly consistent with equilibrium considerations (in particular, with those testable implications provided by Bessembinder and Lemmon, 2002). ${ }^{2}$ Nevertheless, the papers above mentioned use samples that cover around two to three years of data. While this length of sample period may be sufficient to reach sound conclusions when the researcher uses daily-frequency data to uncover intra-daily patterns, it is usually considered to be insufficient to study other patterns with longer horizons, such as monthly or seasonal patterns.

We thus make a significant contribution to the literature on the electricity forward risk premium since, by using ten years of data from one of the oldest spot and futures electricity markets in the world, we circumvent, as far as possible, the statistical difficulties related to the lack of long historical time series that affected other previous studies and cast doubts on the robustness of some of their results. Additionally, as another way of completing the sample, instead of concentrating on a single maturity, we analyze the first four consecutive weekly maturities of the term structure of futures prices traded in Nord Pool.

From a more general perspective, this paper adds to the large body of literature devoted to examining the relationship between spot electricity prices and their related forward or futures prices, by using diverse technical and economic modelling approaches, such as the change-of-probability methodology to pricing derivative securities under the no-arbitrage condition (see, for example, Deng, 1999; Geman and Vasicek, 2001; Kellerhals, 2001; Lucia and Schwartz, 2002; Burger et al., 2004; Cartea

\footnotetext{
2 In a closely related paper, Shawky et al. (2003) briefly investigate the premiums in the CaliforniaOregon border (COB) one-month delivery period futures contracts traded on NYMEX, with up to 180 days to maturity, and find that the average premium increases with the length of the time-to-maturity period.
} 
and Figueroa, 2005; and Pirrong and Jermakyan, 2005). ${ }^{3}$ Finally, this paper also adds to a number of papers devoted to the valuation of the forward and futures contracts traded in Nord Pool, with different objectives, such as: Lucia and Schwartz (2002), Audet et al. (2004), and Koekebakker and Ollmar (2005).

The reminder of this paper is organized as follows. Section 1 summarizes the risk premium approach to futures pricing, and describes and motivates the general features of the empirical research carried out in this paper. It also includes an overview of the empirical findings provided by others following the same general approach in analysing other electricity markets. Section 2 describes the data set used in the study. Section 3 examines the properties of the futures risk premium - including an analysis of its time variation. Section 4 concludes with a summary of the main results and some final remarks.

\section{The risk premium approach to futures pricing and empirical research issues}

\subsection{The risk premium}

In this section we first quickly review, for future reference, some basic wellknown definitions and relationships. ${ }^{4}$ Under the risk premium approach to futures pricing, the futures price is split into the expected spot price on the maturity date and a premium, which is variously known as the risk premium, the futures or forward premium, and the futures or forward bias. To fix notation, let $S(t)$ denote the spot electricity price for electricity to be delivered at time $t$, let $F(t, T)$ denote the futures

\footnotetext{
${ }^{3}$ In these models, risk considerations are made explicit through the so-called market price of risks (linked to the unhedgeable sources of uncertainty included in the models). We do not review here the empirical evidence on the market price of risks obtained in the context of derivative pricing with continuous-time models. This is because the disparate detailed parametric assumptions concerning the dynamics of the underlying state variables, as well as the market price of risks, made by the different models make a direct comparison of their empirical results extremely difficult.

${ }^{4}$ In this paper, we abstract the daily liquidation (marking to market) from the analysis of futures positions. In other words, we consider futures and forward contracts as being indistinguishable. This is an extremely reasonable assumption, provided that we only analyse short-term futures prices in this paper.
} 
price observed on day $t$ for electricity to be delivered at time $T$, and let $P(t, T)$ denote the risk premium. The basic futures pricing equation under the risk premium approach can be written as follows:

$$
F(t, T)=E_{t}[S(T)]+P(t, T),
$$

where $E_{t}[\cdot]$ denotes the conditional expectation operator at time $t$. Notice that every equilibrium model presented in the literature places restrictions on the premium, in the form of specific predictions on the sign and size of the premium as well as its behaviour over time, which provide the empirical researcher with testable hypotheses. In addition, the unobservable expected spot price requires a specification of how expectations are formed in the market.

The above-defined premium is also called the ex ante or expected premium, to be distinguished from the ex post or realized premium, which is defined as the difference between the futures price and the spot price at maturity: $F(t, T)-S(T)$. Now, the two premiums can be related to each other:

$$
F(t, T)-S(T)=P(t, T)+E_{t}[S(T)]-S(T) .
$$

Thus, by definition, the realized premium is the expected risk premium plus any (unanticipated) deviation of the future spot price from the expected future spot price.

For research design reasons, some authors use the basis in their empirical tests of futures premiums. ${ }^{5}$ We define the basis, denoted $B(t, T)$, as the futures price minus the current spot price: $B(t, T)=F(t, T)-S(t)$. Given the basic pricing equation (1), the basis contains information on the expected premium, as well as on the expected change in the spot price:

$$
B(t, T)=P(t, T)+E_{t}[S(T)-S(t)] .
$$

\footnotetext{
${ }^{5}$ See, for example, Fama and French (1987).
} 


\subsection{General empirical research issues}

There are two general approaches in the empirical research of the forward or futures risk premium. The first approach rests on a direct estimation of the ex ante premium, obtained by subtracting an estimate of the expected delivery-date spot price from the observed forward or futures price. This approach is explored, for instance, by Bessembinder and Lemmon (2002), and Karatkasani and Bunn (2005). A serious difficulty with this approach lies in obtaining reliable direct estimates of expected spot prices. ${ }^{6}$

Most papers that analyse the forward risk premium in electricity markets, however, follow an alternative approach that avoids this difficulty. It is based on the analysis of the ex post premium. This is the approach taken in this paper. It is also the approach followed by Geman and Vasicek (2001), Shawky et al. (2003), and Longstaff and Wang (2004), for instance. Bessembinder and Lemmon (2002) and Karakatsani and Bunn (2005) also examine ex post premiums.

This second approach relies on the hypothesis that the observable realized premium equals the ex ante premium plus a random noise, which can be written as

$$
F(t, T)-S(T)=P(t, T)+\varepsilon(t, T),
$$

where $\varepsilon(t, T)$ is the unexpected component of the realized risk premium, and it is a white noise that is orthogonal to (uncorrelated with) information at time $t$. Now, a comparison of (2) and (4) enables the identification of the random noise in (4) with the unexpected component of the realized future spot price (or forecast error): $E_{t}[S(T)]-S(T)=\varepsilon(t, T)$. In other words, under the hypothesis (4), it is assumed that the agents' expectations are formed rationally in the sense that the errors they make in

\footnotetext{
${ }^{6}$ Given the complex behaviour of electricity prices, autoregressive econometric models that link spot prices to related variables are typically used. Predictive intervals (as opposed to point estimates) may help to add robustness to the inferences (see Karatkasani and Bunn, 2005). Alternatively, Longstaff and Wang (2004, section VI) focused on the second moment and compared the volatility of forward and expected spot prices, as an additional test for the presence of forward premiums.
} 
forecasting are zero on average and they are uncorrelated with information they had available at the time of the forecast. ${ }^{7}$

\section{Data description and preliminary analysis}

The Nordic Power Exchange was established in January 1993 in Norway and was progressively expanded to include Sweden, Finland, Denmark, and a German area. The Nord Pool organizes a day-ahead electricity market ("spot physical market") as well as an electricity derivatives market ("financial market"). ${ }^{8}$ In the spot market, 24 hourly power contracts are traded for physical delivery during one specific hour the next day. A price (per MWh), named the system price, is determined separately for each hour for the whole market area through a uniform-price auction, without considering capacity limits in transmission lines. There are a wide range of derivative contracts traded at Nord Pool, including a variety of forward, futures, and option contracts. All forward and futures contracts refer to a base load of one MW during every hour for a given "delivery period" (that ranges from one day to one year in length), and all are settled in cash daily against the system price during the "delivery period".

The sample of spot and futures prices used in this paper was retrieved from the Nord Pool's FTP server files. This paper focuses on the short-term end of the term structure of futures prices. To be precise, the futures data sample consists of a weekly observation of the closing prices for each of the four closest-to-maturity week contracts, from 1 January 1998 to 28 October 2007. Thus, all the examined futures contracts have a final settlement period equal to one-week (from Monday to Sunday). There is no delivery of electricity, since the contracts are settled in cash. Futures prices are given in

\footnotetext{
${ }^{7}$ Fama and French (1987) used the second empirical approach to conduct tests of time-varying risk premiums in large samples of 21 commodity markets, and found it difficult to identify time-varying risk premiums. The much-cited probable reason for this conclusion was also pointed out by Fama and French (1987, p. 73): the large variances of realized premiums as compared to average premiums. The lack of statistical power may also be present in the first alternative approach. Indeed, Bessembinder and Lemmon (2002, p. 1377-78), for example, admitted the imprecision in their estimation of the ex ante forward premiums due to their small sample.

${ }^{8}$ It also provides clearing services for over-the-counter bilateral contracts, which are also allowed in the Nordic area.
} 
Norwegian kroners (NOK) per each contracted megawatt. ${ }^{9}$ The observation dates were chosen to be each Wednesday (or the day before, if it was a non-trading day). ${ }^{10}$ Thus, the sample of futures prices includes four weekly series of futures prices with perfectly homogeneous time-to-delivery periods of slightly less than one, two, three and four weeks to delivery, respectively. By concentrating on weekly observations of the shortterm end of the futures price curve, we manage a small set of four short-term maturities, which simplifies the analysis while still retaining some desirable properties to provide a variety of robust empirical evidence related to the futures premium in electricity markets. Firstly, at Nord Pool, more distant maturities also imply longer delivery periods. By concentrating on contracts with a short delivery period of one week, we are still able to analyse the implications of important seasonal considerations related to the timing of the final settlement period, which is one of the aims of this paper. In addition, although week contracts are listed for trading up to eight weeks before their maturity, we decided to concentrate on the last four week contracts to avoid concerns related to the lack of liquidity. Finally, in contrast to previous studies that concentrated on a single very-short-term forward premium (the day-ahead premium), the analysis of the first four consecutive weekly maturities of the term structure of futures prices traded in the Nord Pool enables the study of time-to-maturity effects on the risk premiums. Additionally, we excluded the first two years of futures data from the analysis (from the end of 1995 to the end of 1997), for two main reasons: to avoid the initial period of the financial market that included relevant changes in the trading system and contractual conditions, and because after 1997 the underlying spot market can be considered an almost definite Nordic multinational market that already included Norway, Sweden and Finland.

The raw spot data retrieved from the Nord Pool's files consisted of twenty-four series (one for each hour during a day) of daily system prices (in Norwegian kroner per $\mathrm{MWh}$ ), for the sample period mentioned above. Since in this paper we examine futures contracts with final settlement periods of one week, we computed a weekly series of

\footnotetext{
${ }^{9}$ Futures prices started to be quoted in euros for the contracts maturing in 2006 . We converted prices in euros into prices in NOKs by using the NOK/euro exchange rate used by the Nord Pool. This rate was very stable during the 2006-2007 period. It ranged from 7.657 to 8.471 , with a mean value of 8.04 and a low standard deviation of 0.17 .

${ }^{10}$ Wednesdays included the lowest number of non-trading days (eight days), which enabled the creation of a set of prices with almost perfectly homogeneous time-to-maturity periods. Furthermore, Wednesdays are unlikely to be the last trading day of the first-to-delivery week contract, so avoiding maturity effects.
} 
underlying spot prices by averaging the 168 system prices ( 24 hours a day times and seven days a week) for each week included in the sample period (from Monday to Sunday). ${ }^{11}$ This weekly average price (per MWh) is taken as the reference underlying spot price in this paper. ${ }^{12}$ Finally, the daily-average system price was also obtained for every Wednesday in the sample, in order to compute the bases, as defined in the previous section.

Hydropower reservoir levels (expressed in percentage over the total hydropower capacity available in the Nord Pool area) were compiled from the second week in 1990 to the end of the above-mentioned sample period. The reservoir levels and capacity data are from the Norwegian Water Resources and Energy Directorate, Svensk Energi (Swedenergy AB), and the Finish Environment Institute (SYKE). Hydro reserves from Sweden and Finland are considered just after their integration in the Nord Pool market (Denmark does not have any hydropower reservoir plant in its power production facilities).

\subsection{Spot prices}

The time series of the weekly-average spot price (the underlying variable for week futures contracts) is plotted in Figure 1, and Table 1 summarizes its most salient statistical properties. ${ }^{13}$

\footnotetext{
${ }^{11}$ Every year, due to the transition from standard time to daylight savings time and vice versa, there is a week in spring with 167 hours as well as a week in autumn with 169 hours.

${ }^{12}$ The arithmetic average of the 24 hourly prices for a given day is used by the Nord Pool as the reference spot price for the daily liquidations in cash during the final "delivery" week. We ignore this daily liquidation. This is extremely reasonable, given the short "delivery periods" (one week) of the contracts that are examined in this paper.

${ }^{13}$ Winter is defined as the period from week number 47 (of one year) to week number 7 (of the next year), both inclusive. The other seasons are defined using consecutive thirteen-week periods. Changes in the spot price series using a couple of prices one season apart were excluded from the analysis by season (this amounts to four observations per year).
} 
FIGURE 1. Weekly-average Spot Prices (1998-2007)

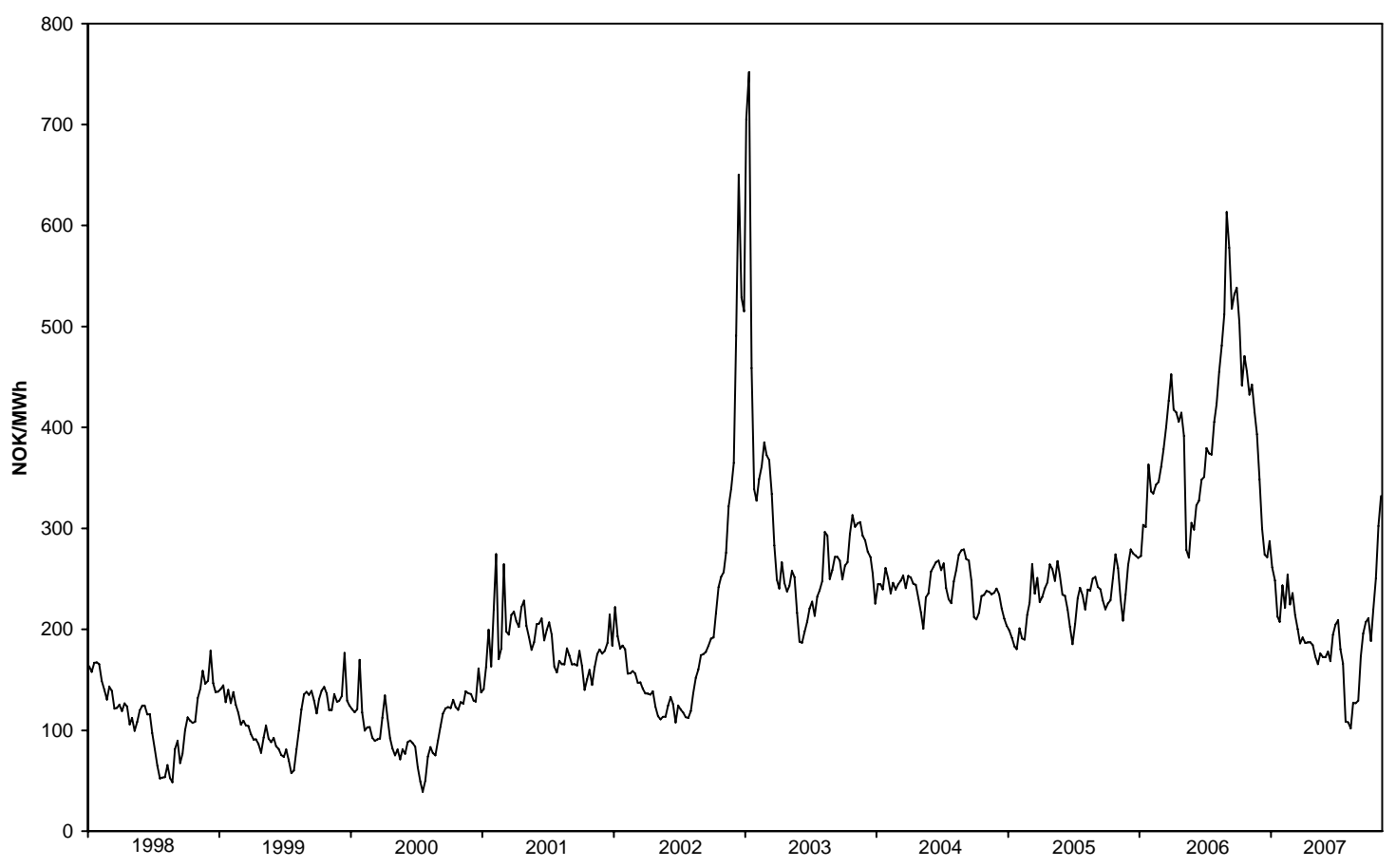

Several well-known properties of spot electricity prices emerge, from inspection of the statistics reported in Table $1 .{ }^{14}$ Firstly, weekly-average electricity prices are highly volatile. ${ }^{15}$ Secondly, extreme electricity prices are relatively frequent, as the above-zero excess kurtosis coefficient indicates, with the extremely high prices being predominant (the distribution of prices is skewed to the right). Thirdly, abnormally large weekly variations (jumps) in prices are relatively frequent in electricity prices, as implied by the large excess kurtosis coefficient for the changes (first differences) in prices (the largest jumps in prices usually form spikes, i.e. temporarily high prices). Fourthly, there are noticeable differences in all the above-mentioned properties across seasons, with the highest standard deviation, excess kurtosis and skewness coefficient of

14 There are several papers that characterize the statistical properties of the Nord Pool daily-average (dayahead) system price with diverse objectives, such as: Wolak (1999), Escribano et al. (2002), Weron et al. (2004), Lucia and Schwartz (2002), and Koopman et al. (2007). Other related Nord Pool spot prices are analysed in Goto and Karolyi (2004) and Haldrup and Nielsen (2004).

15 The standard annualized volatility measure (the standard deviation of the change in the log-price multiplied by the square root of 52) is $80.44 \%$. This value is about four times higher than the usual stock market volatility. 
prices being those of the winter and autumn seasons. Also the standard deviation and excess kurtosis of changes in prices is much higher in winter. Finally, there is a seasonal pattern in the average level of electricity prices over the year: the average value is a $28 \%$ higher in winter than in summer, and the equality of their respective medians is rejected at any significance level with the non-parametric Kruskal-Wallis test (the statistic takes a value of 17.09, which implies a $p$-value of zero).

\section{TABLE 1. Summary Statistics for Weekly-Average Spot Prices (1998-2007)}

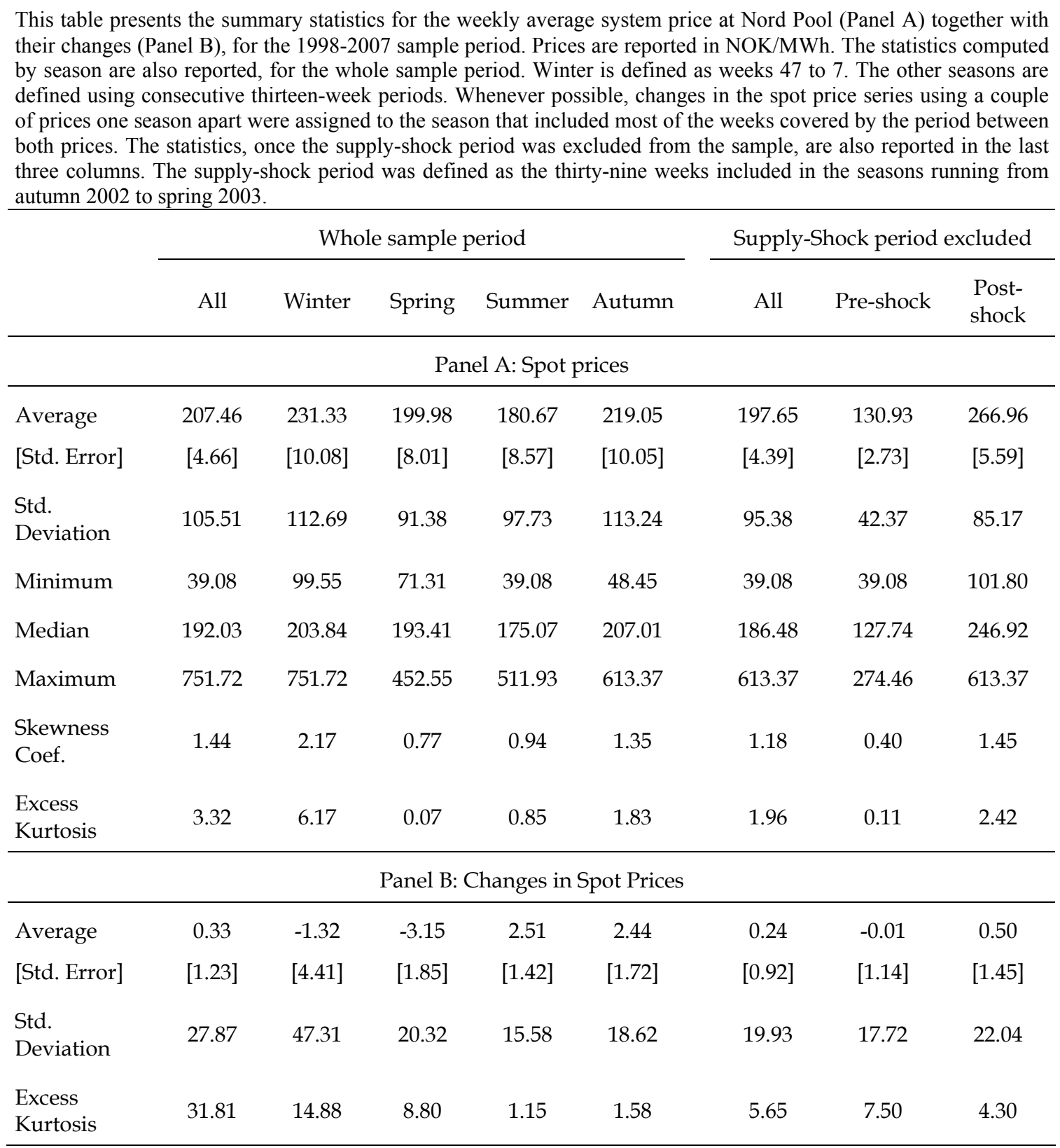


Additionally, a casual look at Figure 1 also reveals an unusually unprecedented turbulent episode in the behaviour of prices around the winter of 2002-2003, together with a distinctive behaviour of prices after this turbulent period, including a second episode of extremely high prices during 2006. A careful examination of the behaviour of prices confirms these facts. The extremely high spot prices around winter 2002-2003 started in late autumn 2002. This fact was probably related to a significant reduction in hydropower production as the abnormally low inflows to the hydro-generation capacity stocks became apparent, close to the beginning of the winter season (which is characterised by low inflows and high demand). ${ }^{16}$ Subsequently, prices reached their historically high record level in January 2003 (weekly-average prices peaked at 751.7 $\mathrm{NOK} / \mathrm{MWh}$, or $339 \%$ higher than the usual winter level measured by the average level for the whole sample period, whereas daily-average prices reached $831 \mathrm{NOK} / \mathrm{MWh}$ ). Spot prices finally fell noticeably during the spring in $2003 .{ }^{17}$ The importance of this supply shock-induced episode for the behaviour of spot prices can be evaluated by analysing the summary statistics once these entire seasons (autumn 2002-spring 2003) are excluded from the sample (see Table 1). The exclusion of this period gives rise to a reduction in mean, median, and maximum values. Also the standard deviation, as well as the skewness and the excess kurtosis coefficients, become lower.

Finally, prices have behaved differently after this unusual period (see Table 1). A comparison of the pre-shock and post-shock periods reveals that weekly-average spot prices have significantly increased (104\% in mean values), and this increment has been accompanied by a significant increase in the dispersion of prices (measured in terms of their variances). ${ }^{18}$ Of course, these two facts are strongly influenced by the second episode of extreme prices that took place in 2006. Additionally, prices show a much less

\footnotetext{
${ }^{16}$ See Von der Fehr et al. (2005), Amundsen and Bergman (2005), and the references contained therein.

${ }^{17}$ This decrease in prices seems to be related to increases in thermal-power generation and electricity imports, as well as a reduction of electricity consumption by price-sensitive end users in Norway (see Von der Fehr et al., 2005, and Amundsen and Bergman, 2005). The issue of whether the observed prices reflect the exercise of market power by major generators has been subject to debate, but there seems to be a lack of convincing proof to support that view (see the above-mentioned references).

${ }^{18}$ Interestingly, Von der Fehr et al. (2005, pp. 76 and 90) reported a noticeable increase in long term (a few years ahead) forward prices of around $140 \%$, from 2002 to the end of 2004 . The equality of variances between both periods is rejected at any significance level with the non-parametric Levene test (it takes a value of 40.88 , which implies a $p$-value of zero).
} 
evident average seasonal pattern in prices (see Figure 1). Although the analysis of the possible reasons behind these facts lie outside the scope of this paper, they seem to indicate tighter market conditions in the Nordic market after the end of year $2002^{19}$.

\section{2. $\quad$ Futures prices and bases}

Similar conclusions can be reached from the analysis of the four week futures prices studied in this paper, because the statistics for the four futures price series, not reported here to save space, are extremely similar to those for the spot price series. This was expected given that the linear correlation coefficient between any future price and the weekly-average spot price is above $97.3 \%$, and the correlation coefficients between any two futures prices are all above $98.8 \%$.

The difference in behaviour between futures prices and spot prices is probably best analysed in terms of the basis. Figure 2 shows the evolution of the four bases (to facilitate comparison, centred moving averages from 13 weekly observations are depicted in Figure 2). The four short-term bases are highly correlated, with the highest correlation coefficients being those for any two bases with consecutive maturities (between $94.3 \%$ and 97.1\%), and the lowest for the two bases with the longest time between maturity dates, i.e. the one-week and the four-week bases $(82.8 \%)$.

Table 2 reports the average values and standard deviations for the four bases. Each basis was computed as the futures price minus the daily-average spot price on the same observational date (see Panel A). For comparison purposes, also the relative bases (in percent) were computed (as one hundred times the basis divided by the futures price) and their statistics are reported in Panel B. Following the previous analysis of the spot price, a seasonal analysis of the bases for the whole sample period was carried out ${ }^{20}$.

19 Von der Fehr et al. (2005) also comment on the factors that may influence the Nordic electricity market conditions after the 2002-2003 events - as well as on what should be expected in the future. They conclude that tighter market conditions, which they expect would give rise to higher and more variable prices, are likely to occur as the over-capacity is eroded and new market-based environmental regulation comes into force, unless a combination of adequate investment incentives and strict competition policy is assured.

${ }^{20}$ Care was taken to assign every basis to the proper season. Whenever possible, the bases computed with a future price with a time-to-maturity period that spread. over two consecutive seasons were assigned to the season that included most of the weeks covered by the time-to-maturity period. By the same criterion, 


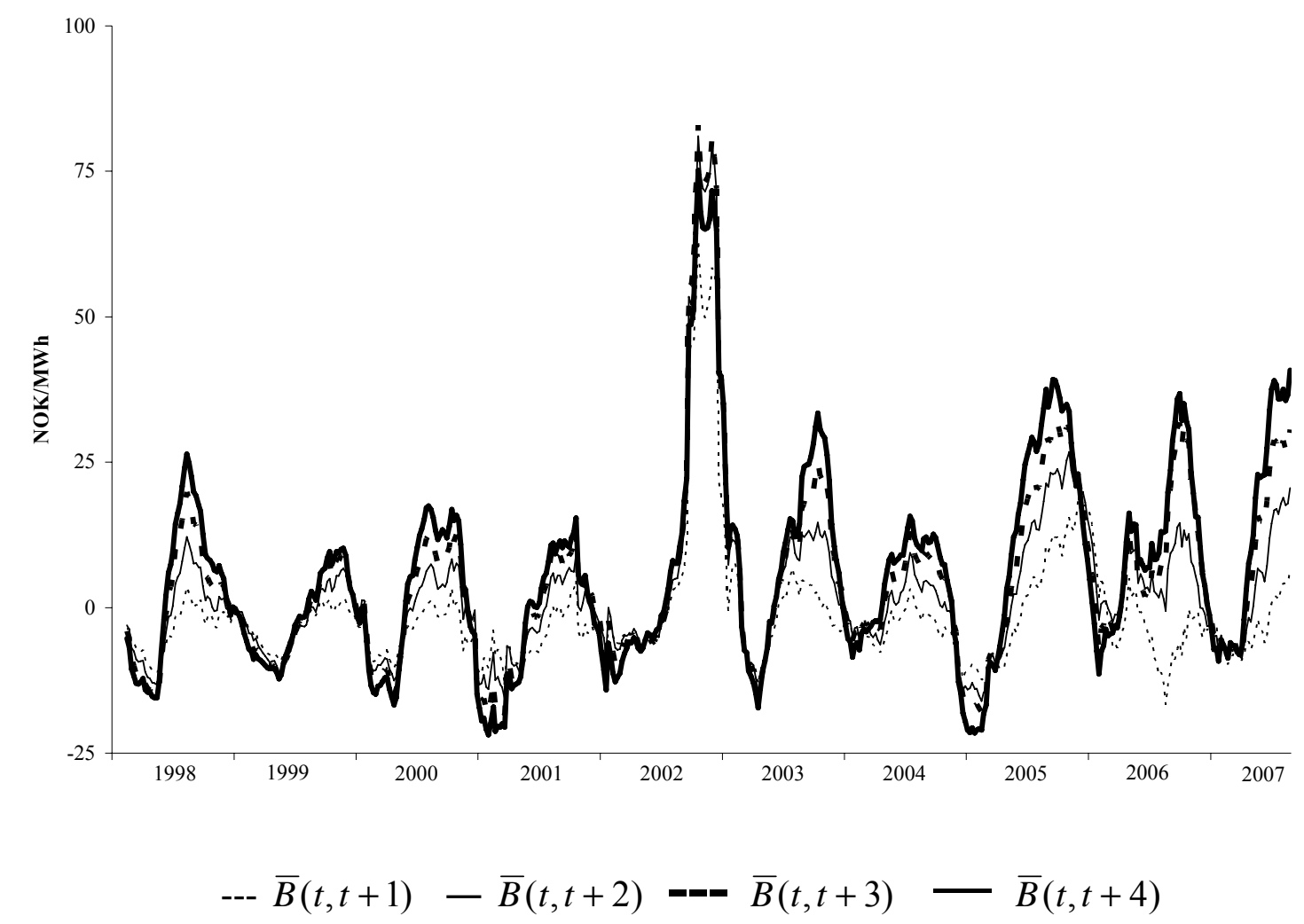

Note: $\bar{B}(t, t+i)$ are centred moving averages from 13 observations of $B(t, t+i)$, with $B(t, t+i)=F(t, t+i)-S(t)$ and $i=1,2,3,4$.

The sign of the basis depends on the time of year, according to standard $t$-tests. The $t$-statistics reported in Table 2 show that the bases are mostly positive in autumn and winter (except the one-week bases, which are zero), negative in spring, and mostly zero in summer (except the one-week basis, which is negative). In addition, most mean values are accompanied by very large standard deviations. ${ }^{21}$

only the one-week bases and the three-week bases that correspond to a time-to-maturity period that is spread over two consecutive seasons could not be assigned to any season, and were excluded from the analysis by season (this amounts to four observations per year). Notice that in order to make the results in in the tables comparable, an analogous criterion was applied to assign premiums to seasons in Table 6 below.

21 Fama and French (1987) report the standard deviations of the six-month relative basis for 21 commodities including metals as well as agricultural, wood and animal products. The standard deviations closest in magnitude to those reported in Table 2 correspond to some animal products. 


\title{
TABLE 2. Summary Statistics for Short-term Futures Bases
}

\begin{abstract}
This table presents the summary statistics for the four bases corresponding to weekly observations of the four nearby week futures contracts traded at Nord Pool, for the 1998-2007 sample period. Each basis is defined as the futures price minus the daily-average spot price on the same observational date. The bases are reported in $\mathrm{NOK} / \mathrm{MWh}$ in Panel A. Also the relative bases (in percentage) are reported in Panel B (the relative basis is defined as one hundred times the basis divided by the futures price). The statistics computed by season are also reported for the whole sample period. Winter is defined as weeks 47 to 7 . The other seasons are defined using consecutive thirteen-week periods. Whenever possible, the bases computed with a future price with a time-to-maturity period that spread over two consecutive seasons were assigned to the season that included most of the weeks covered by the time-to-maturity period.
\end{abstract}

\begin{tabular}{|c|c|c|c|c|c|}
\hline & All & Winter & Spring & Summer & Autumn \\
\hline \multicolumn{6}{|c|}{ Panel A: Basis (NOK/MWh) } \\
\hline & \multicolumn{5}{|c|}{ One week } \\
\hline $\begin{array}{l}\text { Average } \\
{[t \text {-statistic] }}\end{array}$ & $\begin{array}{c}-1.25 \\
{[-1.06]}\end{array}$ & $\begin{array}{c}5.19 \\
{[1.15]}\end{array}$ & $\begin{array}{c}-6.05 \\
{[-3.59]}\end{array}$ & $\begin{array}{c}-4.06 \\
{[-3.62]}\end{array}$ & $\begin{array}{c}0.41 \\
{[0.32]}\end{array}$ \\
\hline \multirow[t]{2}{*}{ Std. Deviation } & 26.74 & 48.16 & 18.48 & 12.26 & 13.91 \\
\hline & \multicolumn{5}{|c|}{ Two weeks } \\
\hline $\begin{array}{l}\text { Average } \\
\text { [t-statistic] }\end{array}$ & $\begin{array}{c}2.77 \\
{[2.10]}\end{array}$ & $\begin{array}{l}12.06 \\
{[2.69]}\end{array}$ & $\begin{array}{c}-6.72 \\
{[-3.89]}\end{array}$ & $\begin{array}{c}-1.13 \\
{[-0.78]}\end{array}$ & $\begin{array}{c}7.40 \\
{[4.88]}\end{array}$ \\
\hline \multirow[t]{2}{*}{ Std. Deviation } & 29.87 & 49.91 & 19.69 & 16.50 & 17.13 \\
\hline & \multicolumn{5}{|c|}{ Three weeks } \\
\hline $\begin{array}{l}\text { Average } \\
\text { [t-statistic] }\end{array}$ & $\begin{array}{c}4.89 \\
{[3.55]}\end{array}$ & $\begin{array}{l}16.78 \\
{[3.59]}\end{array}$ & $\begin{array}{c}-8.82 \\
{[-4.64]}\end{array}$ & $\begin{array}{c}-0.03 \\
{[-0.02]}\end{array}$ & $\begin{array}{l}10.47 \\
{[5.75]}\end{array}$ \\
\hline \multirow[t]{2}{*}{ Std. Deviation } & 31.15 & 49.85 & 20.84 & 20.11 & 19.85 \\
\hline & \multicolumn{5}{|c|}{ Four weeks } \\
\hline $\begin{array}{l}\text { Average } \\
{[t \text {-statistic] }}\end{array}$ & $\begin{array}{c}6.05 \\
{[4.43]}\end{array}$ & $\begin{array}{l}18.03 \\
{[4.53]}\end{array}$ & $\begin{array}{l}-10.26 \\
{[-5.51]}\end{array}$ & $\begin{array}{c}2.38 \\
{[1.18]}\end{array}$ & $\begin{array}{l}14.75 \\
{[7.75]}\end{array}$ \\
\hline Std. Deviation & 30.90 & 44.17 & 21.24 & 22.99 & 21.63 \\
\hline \multicolumn{6}{|c|}{ Panel B: Relative Basis (in \%) } \\
\hline & \multicolumn{5}{|c|}{ One week } \\
\hline $\begin{array}{l}\text { Average } \\
{[t \text {-statistic] }}\end{array}$ & $\begin{array}{c}-1.78 \\
{[-4.51]}\end{array}$ & $\begin{array}{c}0.05 \\
{[0.05]}\end{array}$ & $\begin{array}{c}-4.25 \\
{[-5.25]}\end{array}$ & $\begin{array}{c}-3.11 \\
{[-4.04]}\end{array}$ & $\begin{array}{c}0.43 \\
{[0.69]}\end{array}$ \\
\hline \multirow[t]{2}{*}{ Std. Deviation } & 8.93 & 11.04 & 8.86 & 8.42 & 6.74 \\
\hline & \multicolumn{5}{|c|}{ Two weeks } \\
\hline $\begin{array}{l}\text { Average } \\
{[t \text {-statistic] }}\end{array}$ & $\begin{array}{c}-0.14 \\
{[-0.29]}\end{array}$ & $\begin{array}{c}2.56 \\
{[2.61]}\end{array}$ & $\begin{array}{c}-4.90 \\
{[-5.44]}\end{array}$ & $\begin{array}{c}-1.60 \\
{[-1.55]}\end{array}$ & $\begin{array}{c}3.57 \\
{[5.33]}\end{array}$ \\
\hline \multirow[t]{2}{*}{ Std. Deviation } & 10.75 & 10.89 & 10.26 & 11.73 & 7.58 \\
\hline & \multicolumn{5}{|c|}{ Three weeks } \\
\hline $\begin{array}{l}\text { Average } \\
{[t \text {-statistic] }}\end{array}$ & $\begin{array}{c}0.69 \\
{[1.26]}\end{array}$ & $\begin{array}{c}4.22 \\
{[3.92]}\end{array}$ & $\begin{array}{c}-6.19 \\
{[-6.07]}\end{array}$ & $\begin{array}{c}-1.10 \\
{[-0.82]}\end{array}$ & $\begin{array}{c}5.30 \\
{[6.81]}\end{array}$ \\
\hline \multirow[t]{2}{*}{ Std. Deviation } & 12.47 & 11.51 & 11.18 & 14.76 & 8.49 \\
\hline & \multicolumn{5}{|c|}{ Four weeks } \\
\hline $\begin{array}{l}\text { Average } \\
{[t \text {-statistic] }}\end{array}$ & $\begin{array}{c}1.17 \\
{[1.95]}\end{array}$ & $\begin{array}{c}4.92 \\
{[4.59]}\end{array}$ & $\begin{array}{c}-7.16 \\
{[-7.28]}\end{array}$ & $\begin{array}{c}-0.04 \\
{[-0.03]}\end{array}$ & $\begin{array}{c}7.24 \\
{[8.67]}\end{array}$ \\
\hline Std. Deviation & 13.62 & 11.88 & 11.22 & 16.26 & 9.48 \\
\hline
\end{tabular}


These empirical facts regarding the seasonal behaviour of the bases might be due to a seasonal behaviour of either spot prices or risk premiums (see equation 3 ). ${ }^{22}$ Notice that some equilibrium models can imply a seasonal behaviour in the risk premium (through a seasonal variance of the future spot price, for instance; see Bessembinder and Lemmon, 2002). We will explore in depth the behaviour of the risk premium in the next section.

\subsection{Hydropower reservoir levels}

The links between some variables related to fuel commodities that can be converted into electricity (such as hydro reserves, natural gas, coal, and oil) and electricity prices (spot and futures) have been previously explored by several authors from diverse theoretical and empirical perspectives. ${ }^{23}$ In this paper, we will explore the importance of unusual levels of hydro reservoirs in the explanation of futures premiums in the Nordic electricity market.

Based on the series of hydropower reservoir levels in the Nord Pool area, we computed the historical average level for every week during the 1998-2007 sample period. The historical average level for week $w$ (with $w=1,2, \ldots, 53$ ) in year $y$ (with $y=$ $1998, \ldots, 2007)$ was computed by averaging the reservoir levels in weeks $w$ from year 1990 to year $y-1$. The hydropower reservoir levels in the Nord Pool area together with the historical average series for the 1998-2007 period are plotted in Figure 3.

\footnotetext{
${ }^{22}$ Equivalently, if relationship (1) holds, both the expected deviation from the average seasonal level of spot prices and the value of the risk premium have to be considered when the average seasonal pattern of futures prices is compared to the average seasonality expected for the future spot price. In essence, these are the two possible explanations pointed out by Lucia and Schwartz $(2002$, p. 44) for the empirical evidence that shows that the seasonal term structure of futures prices does not coincide with the seasonal pattern extracted from historical spot data (see Lucia and Schwartz, 2002, p. 41). Borovkova and Geman (2006) take this empirical fact as the main rationale for abandoning the modelling approach that links futures to spot prices and propose a derivatives valuation approach that takes the seasonal pattern in futures prices directly from historical futures data. This approach can be useful to value other derivatives (such as option contracts) issued on futures prices. See also: Eydeland and Geman (1998), and Geman and Vasicek (2001).

${ }^{23}$ In particular, the observation that potential electricity in the form of fuels can be stored has stimulated the exploration of the relationship between electricity and fuel prices under this perspective (see the theoretical paper by Routledge et al., 2001). See Torró (2007) for references on the role of hydro reserves in the determination of spot and futures prices in the Nord Pool market.
} 


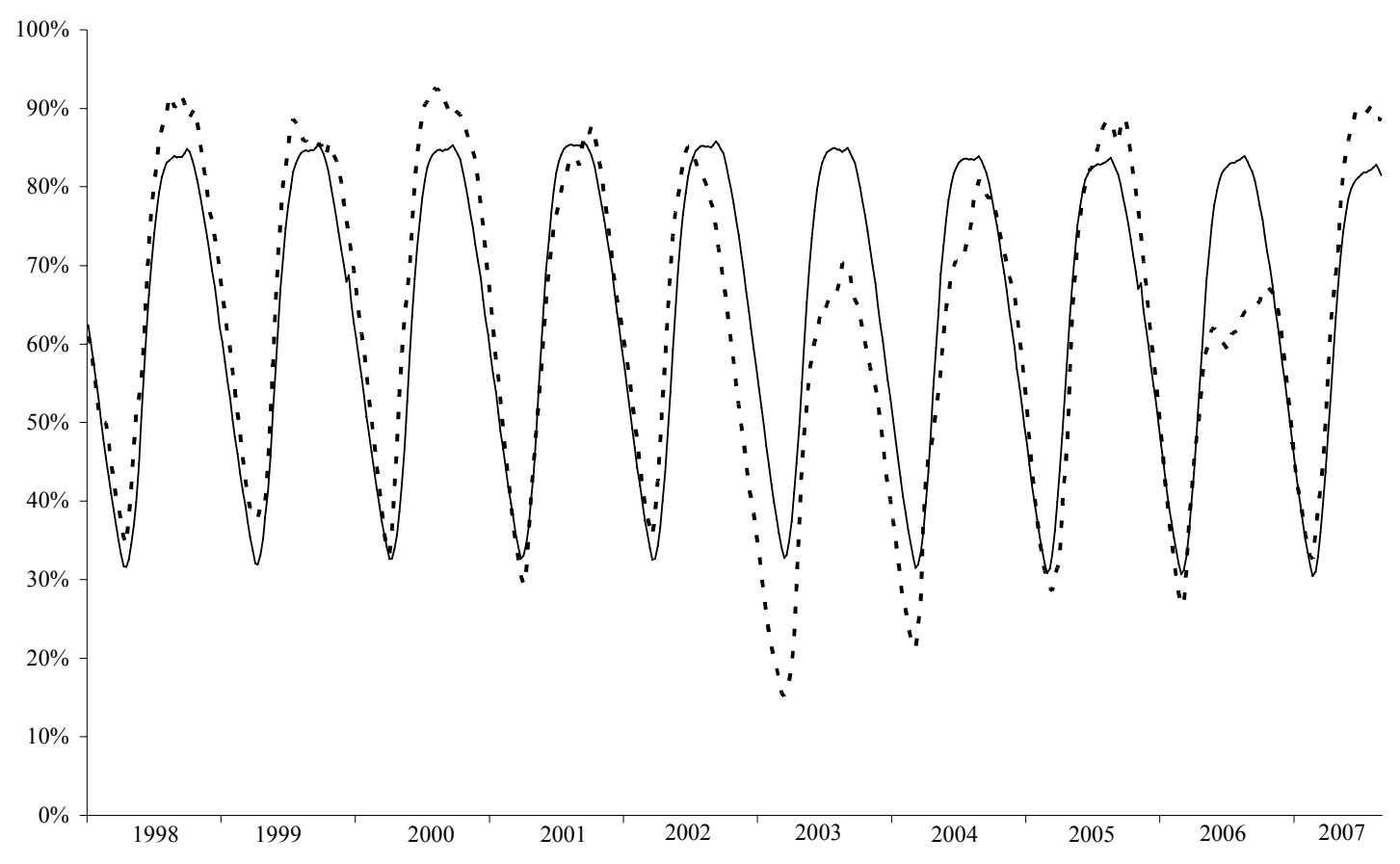

The difference between the two series depicted in Figure 3 can be interpreted as a proxy for the unanticipated deviation from usual hydropower reservoir levels. As such, this supply-side variable is likely to have an influence over spot prices as well as futures prices. Furthermore, there may be reasons to expect that the influence of this difference over both prices may differ depending on its sign. Unusually low (belowaverage) reservoir levels are expected to have a more significant influence on prices than unusually large (above-average) reservoir levels, provided that there are factors (such as the high inelasticity of electricity demand) that imply that prices do not respond equally to being in a situation of tight market conditions (closer to the maximum capacity of the system) than being in a situation of overcapacity. ${ }^{24}$ Since a casual inspection of Figure 3 seems to indicate that unusually low reservoir levels are linked to the tighter market conditions that triggered the turbulent periods in 2002-2003 and

\footnotetext{
${ }^{24}$ As motivational evidence, the positive differences between the historical average and the actual hydro reservoir levels, which indicate unusually low levels, have a linear correlation coefficient of 0.69 with spot prices, whereas the negative differences, which indicate unusually high levels, have a correlation of 0.55 with spot prices.
} 
2006, we will later analyse formally the influence of the below-average reservoir levels (closely related to unexpectedly low hydro reserves) over the relationship between spot and futures prices.

\section{Analysis of risk premiums}

\subsection{Average risk premiums}

We now provide a quick overview of the average realized risk premiums. For every realized risk premium, Table 3 reports the average (together with the $t$-statistic inside brackets), the standard deviation, and the percentage of observational dates in the sample for which the premium is strictly positive. Every premium is computed as the futures price minus the underlying (weekly-average) spot price at maturity. To facilitate comparisons, the statistics for each relative premium (in percent, defined as one hundred times the realized premium divided by the futures price) is also reported in the table. Nonetheless, essentially the same main conclusions are reached from the analysis of either premium.

The average percentage realized premium ranges from $1.7 \%$ per week (the oneweek premium) to $3.3 \%$ per month (the four-week premium). Thus, the average premiums reported above are relatively large when compared to other commodities. ${ }^{25}$ Standard deviations of percentage premiums are also large (they range from $9.4 \%$ to $19.2 \%$, or from 5.1 to 5.8 times the average value). Despite these large standard deviations, the average premiums are positive and significant, according to their $t$ statistics.$^{26}$ Overall, the premiums are positive $60.5 \%$ of the weeks in the sample. In

\footnotetext{
25 As pointed out by Bessembinder and Lemmon (2002, p. 1378), this may indicate that outside speculators are not a significant presence in this type of market and thus the electricity markets are unintegrated with the broader financial markets.

26 Notice that the percentage realized premium coincides with the simple return from a short position taken in a futures contract until maturity. Fama and French (1987) report average monthly simple returns (defined as the change in the futures price over the month divided by the price of the contract at the beginning of the month) for many commodities and they range from $1.91 \%$ per month to $-2.01 \%$ per
} 


\section{TABLE 3. Summary Statistics for Futures Premiums}

This table presents the summary statistics for weekly observations of the four realized premiums corresponding to the four nearby week futures contracts traded at the Nord Pool (Panels A to D), for the 1998-2007 sample period. The percentage of observational dates with positive premiums is reported in the last row in each panel. Every premium was computed as the futures price minus the weekly-average spot price at maturity. The premiums are in NOK/MWh. Also the relative premiums (computed as one hundred times the premium divided by the futures price) are reported. The statistics, once the supply-shock period has been excluded from the sample, are also reported. The supply-shock period was defined as the thirty-nine weeks included in the seasons running from autumn 2002 to spring 2003.

\begin{tabular}{|c|c|c|c|c|c|c|c|c|}
\hline & \multicolumn{4}{|c|}{ Premium in NOK/MWh } & \multicolumn{4}{|c|}{ Relative premium (in \%) } \\
\hline & All & $\begin{array}{c}\begin{array}{c}\text { Supply- } \\
\text { shock }\end{array} \\
\text { period excl. }\end{array}$ & Pre-shock & Post-shock & All & $\begin{array}{c}\text { Supply- } \\
\text { shock } \\
\text { period excl. }\end{array}$ & Pre-shock & Post-shock \\
\hline & \multicolumn{8}{|c|}{ Panel A: One week } \\
\hline $\begin{array}{l}\text { Average } \\
{[t \text {-statistic }]}\end{array}$ & $\begin{array}{c}4.88 \\
{[4.38]}\end{array}$ & $\begin{array}{c}3.67 \\
{[4.51]}\end{array}$ & $\begin{array}{c}1.61 \\
{[1.86]}\end{array}$ & $\begin{array}{c}5.81 \\
{[4.21]}\end{array}$ & $\begin{array}{c}1.66 \\
{[4.01]}\end{array}$ & $\begin{array}{c}1.56 \\
{[3.67]}\end{array}$ & $\begin{array}{c}1.17 \\
{[1.68]}\end{array}$ & $\begin{array}{c}1.96 \\
{[4.15]}\end{array}$ \\
\hline Std. Deviation & 25.18 & 17.67 & 13.50 & 20.98 & 9.37 & 9.21 & 10.80 & 7.18 \\
\hline \multirow[t]{2}{*}{$\begin{array}{l}\text { Days with positive } \\
\text { premium }(\%)\end{array}$} & 60.9 & 60.4 & 60.2 & 60.6 & & & & \\
\hline & \multicolumn{8}{|c|}{ Panel B: Two weeks } \\
\hline $\begin{array}{l}\text { Average } \\
{[t \text {-statistic }]}\end{array}$ & $\begin{array}{c}8.53 \\
{[4.74]}\end{array}$ & $\begin{array}{c}6.93 \\
{[5.52]}\end{array}$ & $\begin{array}{c}3.29 \\
{[2.78]}\end{array}$ & $\begin{array}{l}10.75 \\
{[4.83]}\end{array}$ & $\begin{array}{c}2.73 \\
{[4.46]}\end{array}$ & $\begin{array}{c}2.70 \\
{[4.42]}\end{array}$ & $\begin{array}{c}2.07 \\
{[2.14]}\end{array}$ & $\begin{array}{l}3.35 \\
{[4.61]}\end{array}$ \\
\hline Std. Deviation & 40.65 & 27.25 & 18.41 & 33.77 & 13.82 & 13.24 & 15.05 & 11.04 \\
\hline \multirow[t]{2}{*}{$\begin{array}{l}\text { Days with positive } \\
\text { premium }(\%)\end{array}$} & 58.6 & 59.7 & 58.1 & 61.3 & & & & \\
\hline & \multicolumn{8}{|c|}{ Panel C: Three weeks } \\
\hline $\begin{array}{l}\text { Average } \\
{[t \text {-statistic }]}\end{array}$ & $\begin{array}{l}10.40 \\
{[4.78]}\end{array}$ & $\begin{array}{c}8.86 \\
{[5.62]}\end{array}$ & $\begin{array}{c}4.16 \\
{[2.94]}\end{array}$ & $\begin{array}{l}13.80 \\
{[4.86]}\end{array}$ & $\begin{array}{c}3.14 \\
{[4.18]}\end{array}$ & $\begin{array}{l}3.22 \\
{[4.32]}\end{array}$ & $\begin{array}{c}2.42 \\
{[2.09]}\end{array}$ & $\begin{array}{c}4.07 \\
{[4.40]}\end{array}$ \\
\hline Std. Deviation & 49.13 & 34.17 & 21.97 & 42.96 & 16.96 & 16.17 & 17.99 & 14.00 \\
\hline \multirow[t]{2}{*}{$\begin{array}{l}\text { Days with positive } \\
\text { premium }(\%)\end{array}$} & 60.5 & 61.9 & 61.4 & 62.4 & & & & \\
\hline & \multicolumn{8}{|c|}{ Panel D: Four weeks } \\
\hline $\begin{array}{l}\text { Average } \\
{[t \text {-statistic }]}\end{array}$ & $\begin{array}{l}11.33 \\
{[4.77]}\end{array}$ & $\begin{array}{l}10.12 \\
{[5.55]}\end{array}$ & $\begin{array}{c}4.70 \\
{[3.00]}\end{array}$ & $\begin{array}{l}15.85 \\
{[4.76]}\end{array}$ & $\begin{array}{c}3.30 \\
{[3.88]}\end{array}$ & $\begin{array}{l}3.53 \\
{[4.24]}\end{array}$ & $\begin{array}{c}2.69 \\
{[2.13]}\end{array}$ & $\begin{array}{c}4.42 \\
{[4.12]}\end{array}$ \\
\hline Std. Deviation & 53.51 & 39.52 & 24.35 & 50.29 & 19.15 & 18.05 & 19.66 & 16.18 \\
\hline $\begin{array}{l}\text { Days with positive } \\
\text { premium }(\%)\end{array}$ & 62.2 & 63.3 & 62.2 & 64.5 & & & & \\
\hline
\end{tabular}

month (the average simple returns are positive for 19 of 21 commodities). The standard deviations range from $6.6 \%$ to $12.3 \%$ (they also report standard deviations of two-month premiums that range from $9 \%$ to $18.7 \%$ ). However, the evidence for positive returns was weaker than the number of positive average returns suggested. The average simple returns for only one quarter of the analysed commodities produce $t$-statistics greater than 2.0, and only one provided a $t$-statistic lower than -2.0 . 
addition, non-parametric Kruskal-Wallis tests on the equality of median percentage premiums reported in Table 4, show that any two consecutive percentage premiums are statistically indistinguishable, while the equality of the premiums is rejected at any significance level when the one-week premium is compared to the three-week and the four-week premiums.

\section{TABLE 4. Non-parametric Tests of Equality of Median Relative Futures Premiums}

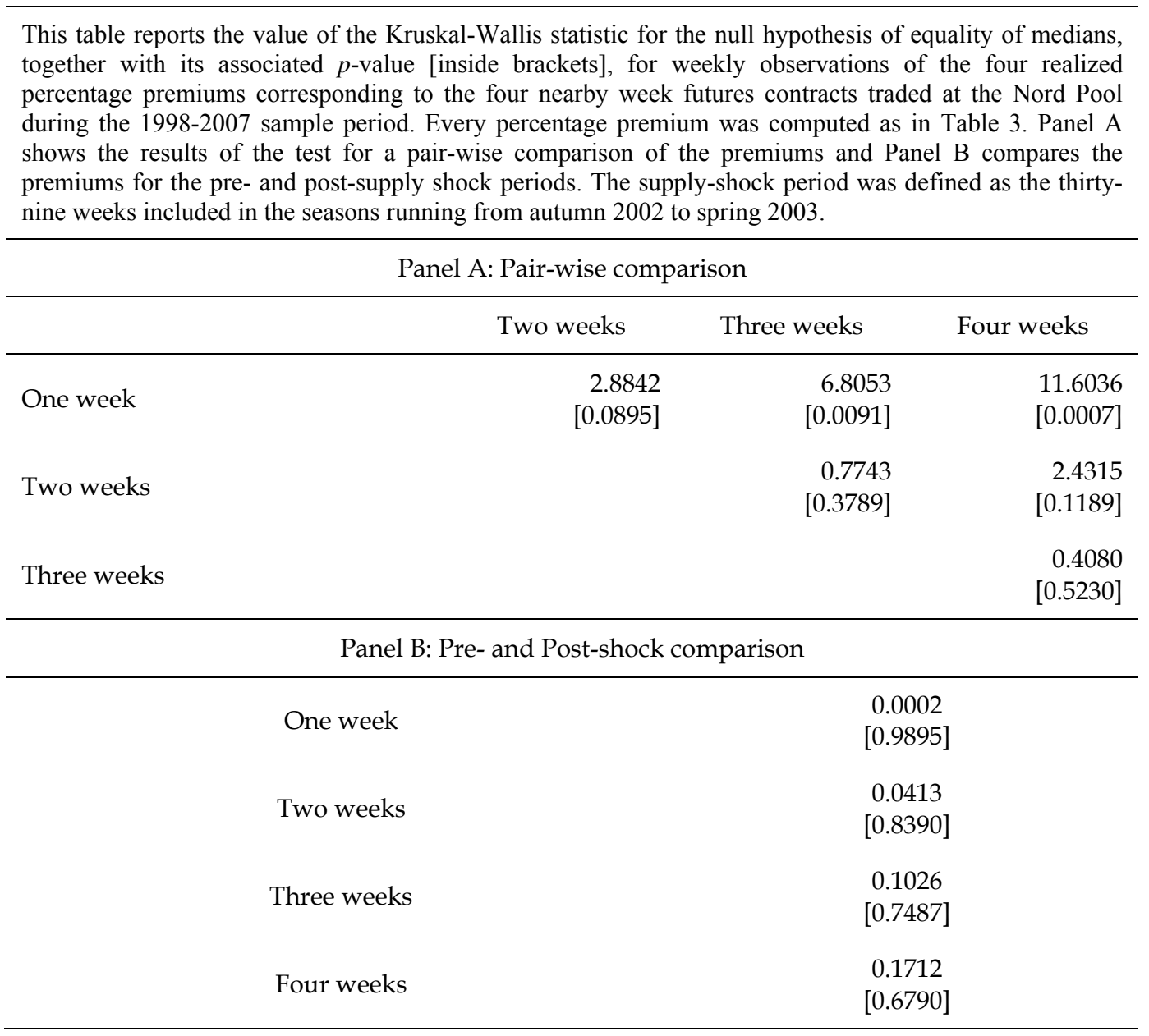

Other important conclusions can be reached from the results reported in Table 3. Firstly, the average percentage premium per unit of risk (computed as the average percentage premium divided by the standard deviation of the percentage premiums) differ little across the four short-term holding periods; they range from 0.17 to 0.20. Secondly, the statistics for the percentage premiums remain very similar after excluding the period of the supply-shock from the sample. Furthermore, the conclusions remain valid once the supply-shock period is excluded from the sample. Hence, they are not due to the extreme events that took place during the 2002-2003 supply-shock period. 
As a brief final comment, the average percentage premiums are around $65 \%$ higher after the 2002-2003 shock period and the standard deviations of the percentage premiums are lower, and consequently, the mean to standard deviation ratios increase noticeably (between 1.9 and 2.6 times) after the crisis. This fact suggests that some things changed after the supply shock. However, in some dimensions the evidence of differences between the pre- and the post-shock periods is much lower than this result suggests. The percentage of weeks with positive premiums is virtually the same after the shock period (see Table 3), and the equality of median percentage premiums between the pre- and the post-shock periods is accepted statistically with the KruskalWallis test (see Table 4, Panel B). ${ }^{27}$

\subsection{Time variation in risk premiums}

We begin with the estimation of an econometric model designed to uncover some general properties of the time variation in electricity short term risk premiums in the Nord Pool market. Then, we explore whether premiums change over time in systematic ways that are consistent with specific equilibrium considerations.

\section{a) A general dynamic model for risk premiums}

Predictable variation in realized premiums is evidence of time-varying expected premiums. Motivated by this remark (Fama and French, 1987, p. 63), we estimate an econometric VAR model designed to provide some general evidence for time variation in the risk premiums contained in electricity futures prices. To be precise, the proposed VAR model is the following:

$$
\begin{aligned}
F(t, t+i)-S(t+i) & =c_{i}+\sum_{j=1}^{p} a_{i, j}[F(t-j, t-j+i)-S(t-j+i)]+\sum_{j=1}^{p} b_{i, j} B(t-j, t-j+i)+d_{i} R_{t-1}^{L}+\varepsilon_{i, t} \\
B(t, t+i) & =c_{i}^{\prime}+\sum_{j=1}^{p} a_{i, j}^{\prime}[F(t-j, t-j+i)-S(t-j+i)]+\sum_{j=1}^{p} b_{i, j}^{\prime} B(t-j, t-j+i)+d_{i}^{\prime} R_{t-1}^{L}+\eta_{i, t}
\end{aligned}
$$

for $i=1,2,3,4$. The ex post risk premiums are computed as $F(t, t+i)-S(t+i)$, where $F(t, t+i)$ represents the futures price traded in $t$ with $i$ weeks to delivery, and $S(t+i)$

\footnotetext{
27 However, the equality of variances between the pre- and the post-shock periods is rejected with the Levene test, at any significance level, for all the premiums except the four-week percentage premium.
} 
stands for the (weekly average) settlement price of the futures contract maturing in $t+i$. The basis is defined as $B(t, t+i)=F(t, t+i)-S_{W}(t)$, where $S_{W}(t)$ is the daily system price on Wednesday at the week $t$. Finally, the dummy variable $R_{t}^{L}$ measures the below-average hydro-reserve level. In brief, it is computed as the historical average level for the same week of the year, minus the current hydro-reserve level, whenever the difference is positive, and zero otherwise. To be precise, $R_{t}^{L}=\max \left(0, \bar{R}_{w, t}-R_{w, t}\right)$. For each observational week $t$, the current hydro-reserve level $R_{w, t}$ is compared to the average level for the same week $w$ of previous years (see section 2.3 above), denoted by $\bar{R}_{w, t}$ (the index $w=1,2, \ldots, 53$, is an ordinal number which indicates the number of the week within the year), and $R_{t}^{L}$ takes the value of the difference if it is positive and zero otherwise.

Thus, in the estimated VAR model, the pair of realized premium and basis is regressed on past realized premiums, past bases, and a proxy for past unexpectedly-low hydro reserves. An autoregressive structure is a simple way of uncovering some general predictable variation in the risk premium. Additionally, we decided to incorporate the basis into a vector autoregressive model that allows for cross-relationships between the premiums and the bases. The determination of some joint predictable variation in both variables has the potential for improving the statistical properties of the estimated model. Finally, as was previously motivated in Section 2, a variable that accounts for unusual reservoir levels is likely to have a significant influence in the Nord Pool market prices. Nonetheless, the influence may be different whenever actual levels are below historical average levels - as compared to the case whenever actual levels are above historical average levels. That is why we split the unusual reservoir levels variable in two. The first, denoted $R_{t}^{L}$, measures the below-average level, and is computed as described above. The second variable measures the above-average level and is defined accordingly. It turned out that only the first variable had an influence on risk premiums and bases. That is why only the variable $R_{t}^{L}$ appears in the final model, equation $(5)^{28}$.

\footnotetext{
28 The econometric model was not designed to explore the relationship between futures prices and future spot prices (through the risk premium and basis concepts), although it is closely related. For a study directly aimed at analysing this relationship for short-term futures prices at the Nord Pool, see Torró (2007).
} 
The four estimated VAR models are reported in Table 5. Some general comments follow. Firstly, risk premiums and bases are mutually related since many cross-coefficients are significant in every VAR model. Secondly, the abnormally low reservoir level coefficient is significant in the eight equations. Thirdly, the adjusted determination coefficient in risk premium equation increases steadily from $28.19 \%$ in the first to delivery until $70.78 \%$ in the fourth to delivery futures contract. In the base equations, the adjusted determination coefficients vary between $13.94 \%$ and $41.62 \%$. Finally, the residual analysis shows that autocorrelation disappeared - but heteroskedasticity remained in the risk premium equations.

\section{b) Time-varying risk premiums and equilibrium analysis}

Motivated by the theoretical findings of equilibrium models in electricity markets we now explore some basic characteristics of the time variation in risk premiums that are consistent with equilibrium. Firstly, we study the seasonal variation in risk premiums. Secondly, we formally test the link between the realized premium and the variance and the skewness of spot prices.

Seasonal variation in the risk premium is broadly consistent with equilibrium. Recall that Bessembinder and Lemmon (2002) proved that the expected forward premium is linearly related (negatively) to the variance of the delivery-date spot price and (positively) to the unstandardised skewness of the spot price. Hence, as Bessembinder and Lemmon (2002) pointed out, seasonal increases in the variance and the coefficient of skewness alike are consistent with an upward variation in the premium. This is because, since the skewness coefficient is the unstandardised skewness (third central moment) normalised by the cube of the standard deviation, the seasonal increase in the skewness coefficient implies that unstandardised skewness increases seasonally more rapidly than the variance. Additionally, small or even negative premiums are consistent with the model, when price variability is moderate and skewness is low. 


\section{TABLE 5. Estimates of the VAR Model on Risk Premiums and Bases}

$$
\begin{aligned}
& \text { This table reports the estimation results for the system: } \\
& \begin{aligned}
F(t, t+i)-S(t+i) & =c_{i}+\sum_{j=1}^{p} a_{i, j}[F(t-j, t-j+i)-S(t-j+i)]+\sum_{j=1}^{p} b_{i, j} B(t-j, t-j+i)+d_{i} R_{t-1}^{L}+\varepsilon_{i, t} \\
B(t, t+i) & =c_{i}^{\prime}+\sum_{j=1}^{p} a_{i, j}^{\prime}[F(t-j, t-j+i)-S(t-j+i)]+\sum_{j=1}^{p} b_{i, j}^{\prime} B(t-j, t-j+i)+d_{i}^{\prime} R_{t-1}^{L}+\eta_{i, t}
\end{aligned}
\end{aligned}
$$

for $i=1,2,3,4$. Every ex post risk premium is computed as $F(t, t+i)-S(t+i)$, where $F(t, t+i)$ represents the futures price traded in $t$ with $i$ weeks to delivery, and $S(t+i)$ stands for the (weekly average) settlement price of the futures contract maturing in $t$ $+i$. The basis is defined as $B(t, t+i)=F(t, t+i)-S_{W}(t)$, where $S_{W}(t)$ is the system price at week $t$ (Wednesday). The dummy variable $R_{t}^{L}$ measures the below-average hydro-reserve level (see the main body of the text for details). Those coefficients and tests with $p$-values lower than $1 \%, 5 \%$ or $10 \%$ are highlighted with one $(*)$, two $(* *)$ and three $\left({ }^{* * *}\right)$ asterisks, respectively. $\bar{R}^{2}$ is the adjusted determination coefficient. Log-l is the value of the log-likelihood function of the system. $Q(16)$ and $Q^{2}(16)$ rows show the Ljung Box tests for sixteenth serial correlation in $\varepsilon_{i, t}$ and $\eta_{i, t}$ and their squares, respectively. Each equation of the VAR system is estimated using ordinary linear squares and the lag is chosen by minimizing the Schwarz Information Criterion (SIC) of the system. The SIC is computed as SIC $=-2(\ell / T)+K \log (T) / T$ where $\ell$ is the logarithm of the likelihood function, $T$ the number of observations and $K$ the number of parameters to estimate.

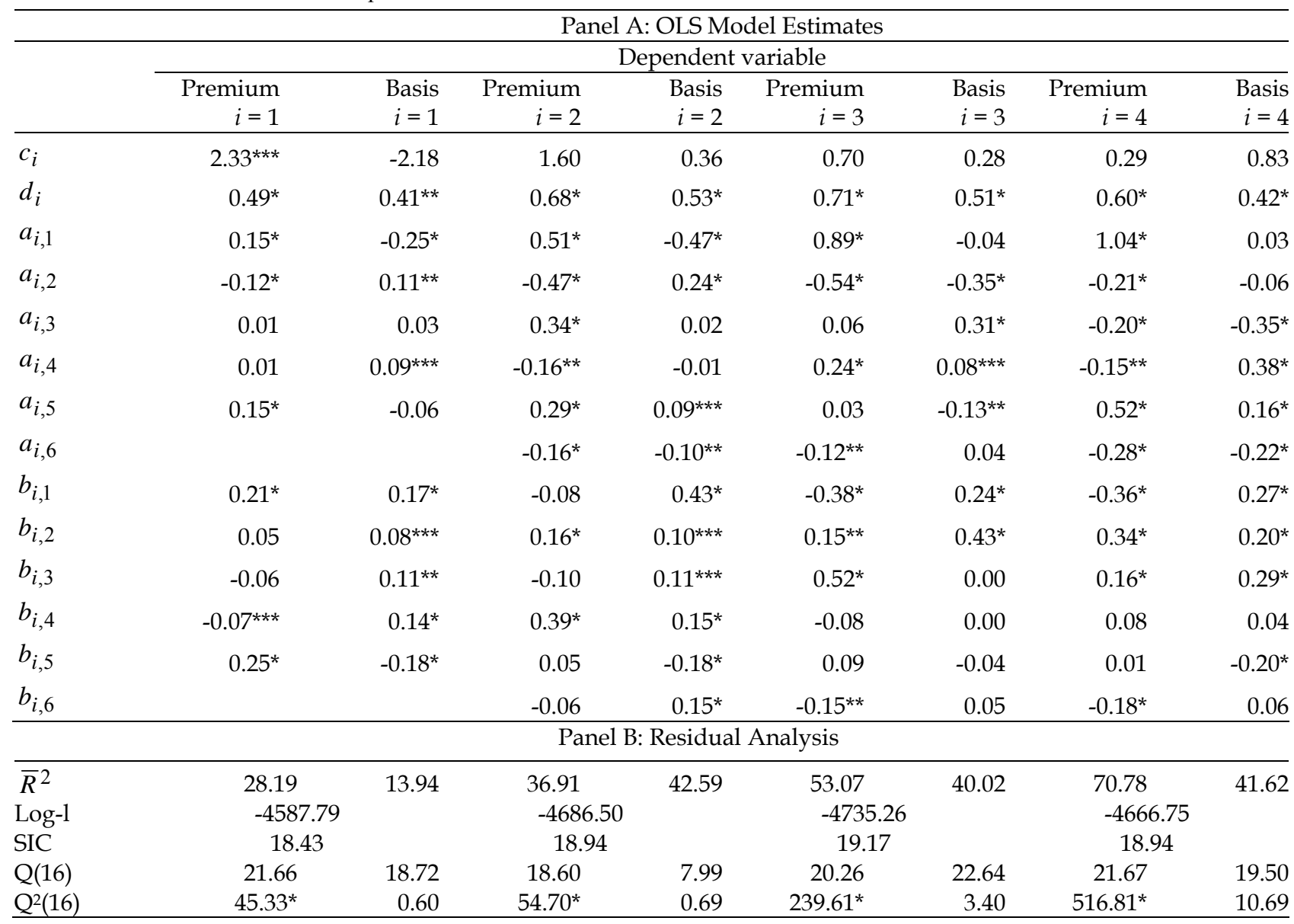


Table 6 reports the summary statistics for the short-term realized risk premiums, by season.

\title{
TABLE 6. Summary Statistics for Short-term Futures Premiums, by Season
}

\begin{abstract}
This table presents the summary statistics for the four realized premiums corresponding to the four nearby week futures contracts traded at Nord Pool, for the 1998-2007 sample period. Each premium is defined as the futures price minus the weekly-average spot price at maturity. The premiums are reported in NOK/MWh. The statistics have been computed by season, for the whole sample period. Winter is defined as weeks 47 to 7 . The other seasons are defined using consecutive thirteen-week periods. Whenever possible, the premium using a future price with a time-to-maturity period that spread over two consecutive seasons were assigned to the season that included most of the weeks covered by the time-to-maturity period.
\end{abstract}

\begin{tabular}{|c|c|c|c|c|}
\hline \multicolumn{5}{|c|}{ Premium in NOK/MWh } \\
\hline & Winter & Spring & Summer & Autumn \\
\hline & \multicolumn{4}{|c|}{ Panel A: One week } \\
\hline $\begin{array}{l}\text { Average } \\
{[t \text {-statistic] }}\end{array}$ & $\begin{array}{l}11.09 \\
{[2.84]}\end{array}$ & $\begin{array}{r}3.85 \\
{[2.31]}\end{array}$ & $\begin{array}{r}1.42 \\
{[1.08]}\end{array}$ & $\begin{array}{r}3.68 \\
{[2.37]}\end{array}$ \\
\hline Std. Deviation & 41.90 & 18.24 & 14.33 & 16.79 \\
\hline Skewness Coef. & 3.05 & 2.13 & 0.63 & 0.88 \\
\hline \multirow[t]{2}{*}{ Days with positive premium (\%) } & 74.8 & 57.5 & 50.0 & 59.8 \\
\hline & \multicolumn{4}{|c|}{ Panel B: Two weeks } \\
\hline $\begin{array}{l}\text { Average } \\
\text { [t-statistic] }\end{array}$ & $\begin{array}{c}18.83 \\
{[3.20]}\end{array}$ & $\begin{array}{r}5.62 \\
{[2.28]}\end{array}$ & $\begin{array}{r}2.09 \\
{[0.95]}\end{array}$ & $\begin{array}{r}8.06 \\
{[3.04]}\end{array}$ \\
\hline Std. Deviation & 65.55 & 28.17 & 24.92 & 29.72 \\
\hline Skewness Coef. & 2.63 & 1.67 & -0.10 & 1.08 \\
\hline \multirow[t]{2}{*}{ Days with positive premium (\%) } & 74.2 & 56.2 & 46.2 & 58.7 \\
\hline & \multicolumn{4}{|c|}{ Panel C: Three weeks } \\
\hline $\begin{array}{l}\text { Average } \\
\text { [t-statistic] }\end{array}$ & $\begin{array}{r}24.74 \\
{[3.32]}\end{array}$ & $\begin{array}{r}7.44 \\
{[2.41]}\end{array}$ & $\begin{array}{r}1.61 \\
{[0.57]}\end{array}$ & $\begin{array}{r}9.97 \\
{[2.98]}\end{array}$ \\
\hline Std. Deviation & 79.52 & 33.83 & 31.19 & 36.06 \\
\hline Skewness Coef. & 2.09 & 1.86 & -0.33 & 0.50 \\
\hline \multirow[t]{2}{*}{ Days with positive premium (\%) } & 73.7 & 56.7 & 50.8 & 60.3 \\
\hline & \multicolumn{4}{|c|}{ Panel D: Four weeks } \\
\hline $\begin{array}{l}\text { Average } \\
{[t \text {-statistic }]}\end{array}$ & $\begin{array}{l}25.04 \\
{[3.41]}\end{array}$ & $\begin{array}{r}7.52 \\
{[2.21]}\end{array}$ & $\begin{array}{r}1.74 \\
{[0.53]}\end{array}$ & $\begin{array}{r}11.77 \\
{[3.05]}\end{array}$ \\
\hline Std. Deviation & 81.54 & 38.75 & 37.32 & 43.10 \\
\hline Skewness Coef. & 1.52 & 1.56 & -0.52 & 0.69 \\
\hline Days with positive premium (\%) & 73.2 & 57.7 & 54.6 & 64.0 \\
\hline
\end{tabular}

The premium is the greatest in winter, and the lowest in summer. According to their $t$-statistics, whereas a significant positive premium is observed in winter, autumn and spring, zero risk premiums are observed in summer. Furthermore, the largest skewness coefficient is in winter and the lowest in summer, hence, the evidence of this seasonal variation in risk premiums is broadly consistent with the equilibrium 
implications mentioned above. Also, the lowest percentage of days with positive premium is in summer and the highest in winter. Additionally, the lowest premium per unit of risk (average divided by the standard deviation) is in summer, and the highest in winter. The average premium per unit of risk in winter is from 2.6 to 6.2 times those of summer.

We now provide some specific evidence on the relationship between the realized premium and the variance and skewness of the spot price. We estimate the following regression:

$$
F(t, t+i)-S(t+i)=a+b \operatorname{Var}[S(t+i)]+c \operatorname{Skew}[S(t+i)]+\varepsilon(t, t+i)
$$

for each maturity $i=1,2,3,4$, where the realized premium with $i$ weeks to maturity is regressed on a constant, the variance of the spot price in week $t+i$, and the unstandardised skewness (the third central moment) of the spot price in week $t+i$. The variance and the skewness of the spot price on the delivery date were computed from the daily system prices from Monday to Sunday in the delivery week. The equilibrium implications of the model by Bessembinder and Lemmon (2002) are that $b$ should be strictly negative and $c$ positive. Their theoretical finding, however, holds for the ex ante premium, hence the constant $a$ included in the regression above is interpreted in equilibrium as the mean prediction error (see relationship (4)). If the forecast error is positive (respectively, negative) in average, this implies that agents overestimated (underestimated) the spot price at maturity.

Table 7 reports the estimation results for the whole sample period (1998-2007) in Panel A. Additionally, motivated by our previous empirical findings on the distinctive behaviour of prices before and after the autumn 2002-spring 2003 supplyshock period, we repeated the analysis independently for both periods. The regression results are also reported in Table 7 , Panels B and C.

The estimation results indicate that the model is not valid for the whole sample period. The coefficient estimates on the variance and the skewness are not statistically significant, and the coefficients of determination are very low. 


\section{TABLE 7. Regression of Risk Premium on Variance and Skewness of Spot Prices}

This table reports coefficient estimates and $t$-statistics [inside brackets] from estimating the following regression:

$F(t, t+i)-S(t+i)=a+b \operatorname{Var}[S(t+i)]+c \operatorname{Skew}[S(t+i)]+\varepsilon(t, t+i)$,

for $i=1,2,3$, and 4 . The $t$-statistics are based on Newey-West consistent estimators of the covariance matrices. Significance of the coefficients at the $1 \%, 5 \%$ and $10 \%$ levels are indicated with one $(*)$, two $(* *)$ and three (***) asterisks, respectively. The $R$-squared statistic (in per cent) is reported in the last column. The regression has been estimated for the whole sample period 1998-2007 (Panel A), for the sub-period before autumn 2002 (Panel B), and for the sub-period after spring-2003 (Panel C).

\begin{tabular}{|c|c|c|c|c|}
\hline & $a$ & $b$ & $c$ & $R^{2}(\%)$ \\
\hline \multicolumn{5}{|c|}{ Panel A: Whole sample (weeks: 2/1998-43/2007) } \\
\hline One week & $\begin{array}{r}3.30 \\
{[2.39]^{* *}}\end{array}$ & $\begin{array}{r}0.005191 \\
{[1.56]}\end{array}$ & $\begin{array}{r}-0.000023 \\
{[-2.30]^{* *}}\end{array}$ & 5.78 \\
\hline Two weeks & $\begin{array}{r}7.56 \\
{[3.47]^{*}}\end{array}$ & $\begin{array}{r}0.003302 \\
{[0.69]}\end{array}$ & $\begin{array}{r}-0.000016 \\
{[-1.18]}\end{array}$ & 1.13 \\
\hline Three weeks & $\begin{array}{r}10.93 \\
{[3.48]^{*}}\end{array}$ & $\begin{array}{r}-0.000813 \\
{[-0.14]}\end{array}$ & $\begin{array}{r}-0.000007 \\
{[-0.41]}\end{array}$ & 0.84 \\
\hline Four weeks & $\begin{array}{r}11.42 \\
{[3.06]^{*}}\end{array}$ & $\begin{array}{r}0.000640 \\
{[0.11]}\end{array}$ & $\begin{array}{r}-0.000014 \\
{[-0.85]}\end{array}$ & 1.14 \\
\hline \multicolumn{5}{|c|}{ Panel B: Pre-shock period (weeks: 2/1998-33/2002) } \\
\hline One week & $\begin{array}{r}3.59 \\
{[3.43]^{*}}\end{array}$ & $\begin{array}{r}-0.008167 \\
{[-3.60]^{*}}\end{array}$ & $\begin{array}{r}0.000015 \\
{[2.16]^{* *}}\end{array}$ & 30.51 \\
\hline Two weeks & $\begin{array}{r}6.15 \\
{[3.50]^{*}}\end{array}$ & $\begin{array}{r}-0.013705 \\
{[-3.00]^{*}}\end{array}$ & $\begin{array}{r}0.000033 \\
{[2.42]^{* *}}\end{array}$ & 19.47 \\
\hline Three weeks & $\begin{array}{r}7.29 \\
{[3.22]^{*}}\end{array}$ & $\begin{array}{r}-0.014207 \\
{[-3.04]^{*}}\end{array}$ & $\begin{array}{r}0.000031 \\
{[2.28]^{* *}}\end{array}$ & 20.22 \\
\hline Four weeks & $\begin{array}{r}8.08 \\
{[3.07]^{*}}\end{array}$ & $\begin{array}{r}-0.015346 \\
{[-2.61]^{*}}\end{array}$ & $\begin{array}{r}0.000034 \\
{[1.98]^{* *}}\end{array}$ & 19.25 \\
\hline \multicolumn{5}{|c|}{ Panel C: Post-shock period (weeks: 21/2003-43/2007) } \\
\hline One week & $\begin{array}{r}2.95 \\
{[1.79]^{* * *}}\end{array}$ & $\begin{array}{l}0.005008 \\
{[1.69]^{* * *}}\end{array}$ & $\begin{array}{r}-0.000178 \\
{[-4.41]^{*}}\end{array}$ & 26.26 \\
\hline Two weeks & $\begin{array}{r}9.13 \\
{[2.93]^{*}}\end{array}$ & $\begin{array}{r}0.001571 \\
{[0.43]}\end{array}$ & $\begin{array}{r}-0.000181 \\
{[-6.45]^{*}}\end{array}$ & 7.82 \\
\hline Three weeks & $\begin{array}{r}12.40 \\
{[2.64]^{*}}\end{array}$ & $\begin{array}{r}0.001424 \\
{[0.27]}\end{array}$ & $\begin{array}{r}-0.000158 \\
{[-4.20]^{*}}\end{array}$ & 3.68 \\
\hline Four weeks & $\begin{array}{r}14.81 \\
{[2.51]^{\star *}}\end{array}$ & $\begin{array}{r}0.000593 \\
{[0.10]}\end{array}$ & $\begin{array}{r}-0.000152 \\
{[-3.25]^{*}}\end{array}$ & 2.32 \\
\hline
\end{tabular}

The estimation results for the pre-shock period, however, are totally different. Firstly, all the coefficient estimates are statistically significant at the usual levels (all are significant at the $1 \%$ level, except the coefficients on the skewness, which are significant at the 5\% level). Secondly, the signs of the coefficient estimates on the variance and the skewness are as predicted by the equilibrium model. Thirdly, the 
estimate for the constant coefficient is positive, which indicates that risk premiums are only partially determined by the variance and the skewness of future spot electricity prices. Fourthly, the $R^{2}$ statistics are around $20 \%$. Hence, the estimation results for the pre-shock period are consistent with the view of market participants that determine futures prices, at least partially, based on risk considerations.

Finally, the estimations for the post-shock period provide inconclusive results. The coefficient estimates on the skewness are significant. However, the coefficients on the variance are not significant, except for the one-week premium case, which is significant at the $10 \%$ level. Furthermore, the signs of the significant coefficient estimates are the opposite of those obtained for the pre-shock period. Nonetheless, the coefficients of determination are very low, except for the one-week premium case. These results imply that premiums are no longer linked to risk variables as predicted by the Bessembinder and Lemmon model after the shock period. Since any test of the predictions of an equilibrium model is a joint test of the equilibrium in the market and the hypothesis of the model, this result may be due either to the fact that the Nord Pool is no longer in equilibrium, or that the model is not a valid description of the Nord Pool market after the crisis. Overall, these results suggest once again that circumstances changed in the Nord Pool market after the late 2002-early 2003 turbulent period.

\section{c) Analysis of the 2002-2003 turbulent period}

Now, it is also worth exploring the 2002-2003 supply-shock period in detail. The objective of this analysis is twofold. Firstly, conclusions on the behaviour of the premium during this unusual period are also relevant to understand the inconclusive results obtained for the whole sample period 1998-2007. Secondly, a closer look at the unusual period may help understand how agents reacted to the unprecedented circumstances that they faced temporarily around the end of 2002.

The evolutions of the four risk premiums for the period that runs from autumn 2002 to spring 2003 are plotted in Figure 4. During the turbulent period, the premiums are at first unusually large and negative, and then changed to being unusually large and positive. Based on this observation, we split this turbulent period into two sub-periods. Then, we estimated regression (6) for the whole shock period (autumn 2002 - spring 2003), and for the two sub-periods. The estimation results are reported in Table 8. 
FIGURE 4. Risk Premiums during the Supply-shock Period (Autumm 2002-Spring 2003)

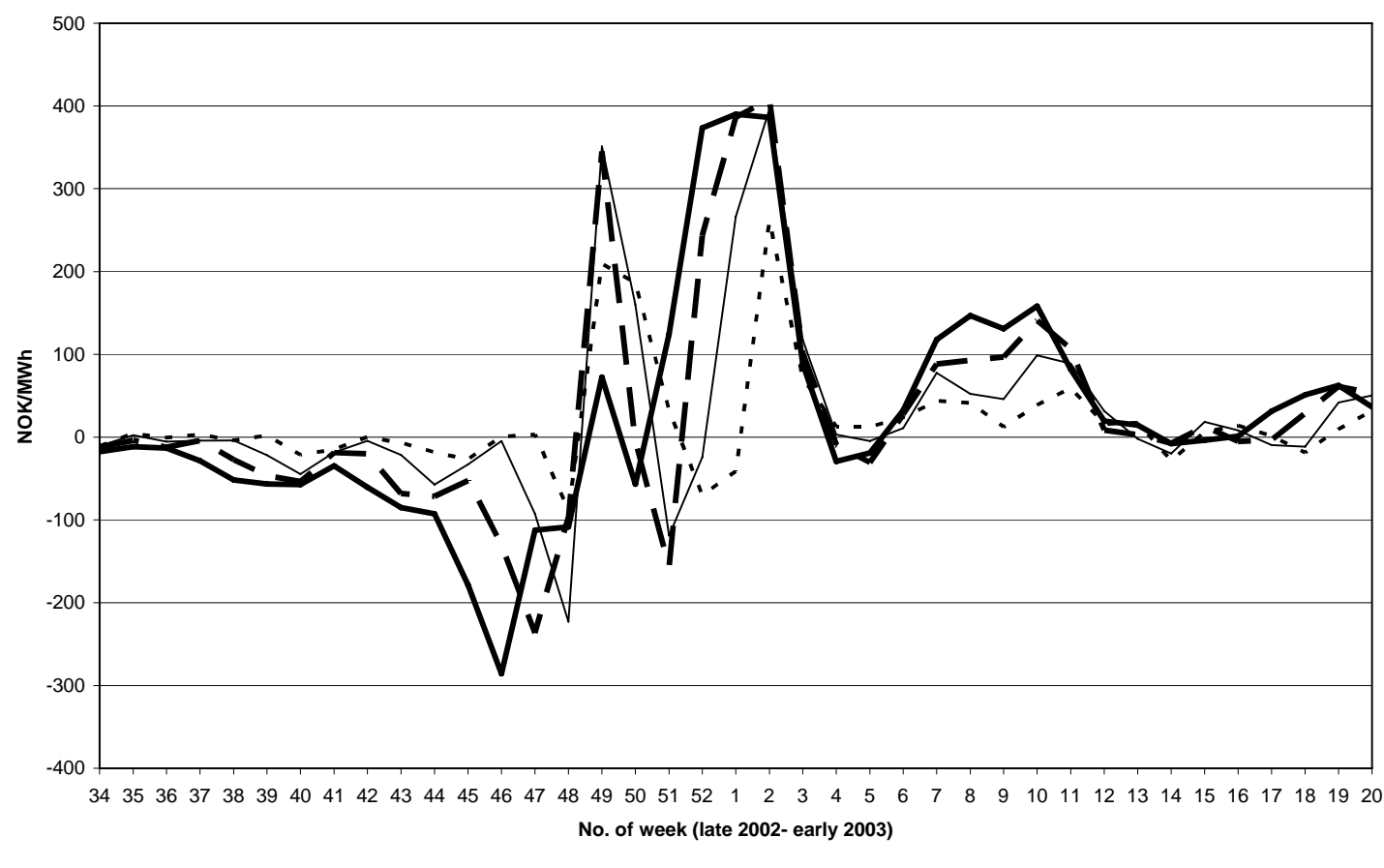

--- One week - Two weeks --- Three weeks - Four weeks

The estimation results for the whole unusual period are reported in Panel A. They show that only the coefficient estimate on the skewness is significant (at the $1 \%$ level, except for the four-week premium, which is significant at the $5 \%$ level). The $R^{2}$ s, however, vary a great deal. They range from $37 \%$ for the one-week premium to $4 \%$ for the four-week premium. A closer analysis of the period helps to understand these results. Table 7 (Panels $\mathrm{B}$ and $\mathrm{C}$ ) also report the estimation results for the first subperiod, which is characterized by unusually low (negative) premiums (from week 34 to week number 48 in 2002), and for the second sub-period, which starts in week 49 and is mainly characterized by unusually large positive premiums (see Figure 4).

The results for the first case (Panel B) show essentially the same results for all the premiums except the one-week premium, whose results are less clear-cut. Firstly, most coefficients are significant at the $1 \%$ level. Secondly, the coefficients on the variance and the skewness have the sign predicted by the theory in equilibrium. Thirdly, the constant coefficient is negative and large, which indicates that agents underpredicted the spot price at maturity. Fourthly, $R^{2}$ statistics range from $68 \%$ to $90 \%$. In summary, estimation results for the first case are consistent with agents that price futures contracts mainly based on risk considerations and, at the same time, made large 
negative forecast errors. These predictive errors can be explained by the temporary and unpredictable events that took place during such period (the unprecedented low reservoir levels that gave rise to unprecedented high price levels).

TABLE 8. Regression of Risk Premium on Variance and Skewness of Spot Prices: Analysis of the Supply-shock Period

This table reports coefficient estimates and $t$-statistics [inside brackets] from estimating the following regression:

$$
F(t, t+i)-S(t+i)=a+b \operatorname{Var}[S(t+i)]+c \operatorname{Skew}[S(t+i)]+\varepsilon(t, t+i),
$$

for $i=1,2,3$, and 4 . The $t$-statistics are based on Newey-West consistent estimators of the covariance matrices. Significance of the coefficients at the $1 \%, 5 \%$ and $10 \%$ levels are indicated with one $(*)$, two $(* *)$ and three $(* * *)$ asterisks, respectively. The $R$-squared statistic (in per cent) is reported in the last column. The regression has been estimated for the whole supply-shock period: autumn 2002-spring 2003 (Panel A); for the sub-period from the $34^{\text {th }}$ week of 2002 to the $48^{\text {th }}$ week of 2002 (Panel B), and for the sub-period running from week no. 49 year 2002 to week no. 20 year 2003 (Panel C).

\begin{tabular}{|c|c|c|c|c|}
\hline & $a$ & $b$ & $c$ & $R^{2}(\%)$ \\
\hline \multicolumn{5}{|c|}{ Panel A: Whole supply-shock period (weeks: 34/2002-20/2003) } \\
\hline One week & $\begin{array}{r}14.39 \\
{[1.48]}\end{array}$ & $\begin{array}{r}0.003355 \\
{[1.33]}\end{array}$ & $\begin{array}{r}0.000167 \\
{[17.18]^{*}}\end{array}$ & 37.09 \\
\hline Two weeks & $\begin{array}{r}24.58 \\
{[1.47]}\end{array}$ & $\begin{array}{r}0.001467 \\
{[0.35]}\end{array}$ & $\begin{array}{r}0.000208 \\
{[5.07]^{*}}\end{array}$ & 18.33 \\
\hline Three weeks & $\begin{array}{l}34.82 \\
{[1.29]}\end{array}$ & $\begin{array}{r}-0.005854 \\
{[-1.04]}\end{array}$ & $\begin{array}{r}0.000235 \\
{[8.62]^{*}}\end{array}$ & 15.63 \\
\hline Four weeks & $\begin{array}{r}28.31 \\
{[0.79]}\end{array}$ & $\begin{array}{r}-0.002387 \\
{[-0.33]}\end{array}$ & $\begin{array}{r}0.000128 \\
{[2.60]^{* *}}\end{array}$ & 4.31 \\
\hline \multicolumn{5}{|c|}{ Panel B: First sub-period (weeks: 34/2002-48/2002) } \\
\hline One week & $\begin{array}{r}-4.67 \\
{[-1.92]^{* * *}}\end{array}$ & $\begin{array}{r}-0.010477 \\
{[-9.39]^{*}}\end{array}$ & $\begin{array}{r}-0.001522 \\
{[-2.46]^{* *}}\end{array}$ & 87.05 \\
\hline Two weeks & $\begin{array}{r}-17.16 \\
{[-2.83]^{* *}}\end{array}$ & $\begin{array}{r}-0.016721 \\
{[-13.98]^{*}}\end{array}$ & $\begin{array}{r}0.002041 \\
{[16.96]^{*}}\end{array}$ & 90.49 \\
\hline Three weeks & $\begin{array}{r}-37.47 \\
{[-3.15]^{*}}\end{array}$ & $\begin{array}{r}-0.025027 \\
{[-3.55]^{*}}\end{array}$ & $\begin{array}{r}0.001164 \\
{[3.23]^{*}}\end{array}$ & 67.72 \\
\hline Four weeks & $\begin{array}{r}-56.08 \\
{[-3.56]^{*}}\end{array}$ & $\begin{array}{r}-0.030117 \\
{[-4.15]^{*}}\end{array}$ & $\begin{array}{r}0.001416 \\
{[3.85]^{*}}\end{array}$ & 70.84 \\
\hline \multicolumn{5}{|c|}{ Panel C: Second sub-period (weeks: 49/2002-20/2003) } \\
\hline One week & $\begin{array}{r}30.61 \\
{[2.13]^{* *}}\end{array}$ & $\begin{array}{r}0.004235 \\
{[1.16]}\end{array}$ & $\begin{array}{r}0.000164 \\
{[7.96]^{*}}\end{array}$ & 45.41 \\
\hline Two weeks & $\begin{array}{r}63.35 \\
{[2.36]^{* *}}\end{array}$ & $\begin{array}{r}0.001114 \\
{[0.19]}\end{array}$ & $\begin{array}{r}0.000193 \\
{[6.13]^{*}}\end{array}$ & 22.51 \\
\hline Three weeks & $\begin{array}{r}91.24 \\
{[2.36]^{* *}}\end{array}$ & $\begin{array}{r}-0.007072 \\
{[-1.47]}\end{array}$ & $\begin{array}{r}0.000226 \\
{[16.69]^{*}}\end{array}$ & 22.12 \\
\hline Four weeks & $\begin{array}{r}95.88 \\
{[2.24]^{* *}}\end{array}$ & $\begin{array}{r}-0.003146 \\
{[-0.54]}\end{array}$ & $\begin{array}{r}0.000118 \\
{[3.32]^{*}}\end{array}$ & 7.03 \\
\hline
\end{tabular}


However, results are totally different for the second sub-period (Panel C). The constant coefficient is significant at the $5 \%$ level, positive, and very large. The coefficient on the variance is not statistically significant, and the coefficient on skewness is significant at the $1 \%$ level, and positive. The $R^{2}$ s vary a great deal (they range from $7 \%$ to $45 \%$ ). Hence, the situation changed from week 49 of 2002 onwards. Firstly, from results displayed in Table 7, Panel C, it seems that agents temporarily reacted to the unprecedented previous situation by greatly increasing the average premiums (the value of the constant term in the regression ranges from 30.6 to almost 96, in NOK/MWh). Furthermore, these huge increments in the premiums are only partially related to risk measures (only the coefficient estimates on the skewness are statistically significant). Secondly (see Table 7, Panel C), after the end of this initial period, average premiums decreased noticeably (compare the constant coefficient estimates), and they are no longer linked to risk variables as predicted by the Bessembinder and Lemmon model.

\section{Conclusions}

This paper examines the relationship between electricity futures and spot prices through the futures risk premium concept, by analysing a large sample of data for a set of four short-term futures contracts traded at the Nord Pool market, which spans over a decade. Our results confirm the existence of risk premiums in electricity markets, whose significance varies throughout the year. We are also able to provide support to the view that Nord Pool market participants priced futures contracts mainly based on risk considerations, until the unprecedented circumstances that shocked the market around the winter 2002-2003.

First of all, we find that the risk premiums are positive on average. Although this is not typically the case with other commodities, this result is in line with some evidence recently found in several electricity markets. Nevertheless, we further examine the time variation in the premiums and we find that the significance of the premiums varies a great deal throughout the year. It is zero in spring and summer, positive in autumn, and the largest in winter. This fact is also consistent with some available empirical evidence that points out that the risk premium in electricity markets is large and positive for those contracts with delivery during demand peak periods. Interestingly, this fact can be explained in the context of some theoretical model for electricity prices. Indeed, it is consistent with the prediction of the Bessembinder and 
Lemmon model (2002) that when expected demand is high relative to capacity or when demand is more variable (as might be expected during the intemperate weeks of the year), the distribution of spot power prices becomes positively skewed. The futures price is increased to compensate for the skewness, since short futures positions incur large losses if upward spikes in spot prices occur. We also document that supply-side variables, such as the unexpectedly low hydro capacity, has additional explicative power over past premiums and bases in explaining future premiums. This confirms the important role of tighter market conditions in explaining the behaviour of the relationship between futures and spot electricity prices.

Additionally, our results link the premiums to the variance and the skewness of electricity spot prices. In particular, we find that, before the unprecedented turbulent period that took place around the end of the year 2002, futures premiums were negatively related to price variance and positively related to price skewness. This result provides some support for the model for electricity forward and spot markets elaborated by Bessembinder and Lemmon (2002). Thus, this result is consistent with the view of market participants that used to price futures contracts, at least partially, on risk considerations.

Finally, we also provide sound evidence that strongly suggests that circumstances changed in the Nord Pool market after the winter of 2002-2003. In particular, we show that spot prices have noticeably increased after the turbulent period, and also that the seasonal patterns seem to have faded away. These facts are consistent with tighter conditions in the Nordic electricity area. We also find that the risk premiums are larger after the shock period, and that the Bessembinder and Lemmon (2002) implications do not hold after the winter of 2002-2003. This suggests that this model is no longer a valid description of the Nord Pool market and their participants from 2003 onwards. Whether the new situation will become permanent, or not, will only be confirmed in the coming years. 


\section{References}

AUDET, N., HEISKANEN, P., KEPPO, J. AND VEHVILÄINEN, I. (2004): "Modelling electricity forward curve dynamics in the Nordic market". Chapter 12, in Bunn D.W. (editor), Modelling prices in competitive electricity markets, Wiley, 251-265.

AMUNDSEN, E.S. AND BERGMAN L. (2005): Why has the Nordic electricity market worked so well? Working papers in Economics, No. 18/05, Department of Economics, University of Bergen.

BESSEMBINDER, H. AND LEMMON, M.L. (2002): Equilibrium Pricing and Optimal Hedging in Electricity Forward Markets. The Journal of Finance, 57, 1347-82.

BOROVKOVA, S. AND GEMAN, H. (2006): Analysis and modelling of electricity futures prices. Studies in nonlinear dynamics and econometrics, 10, 3, 6 .

BOTTERUD, A., BHATTACHARYYA, A.K., AND ILIC, M. (2002): Futures and Spot Prices - an Analysis of the Scandinavian Electricity Market. Proceedings of the $34^{\text {th }}$ Annual North American Power Symposium, October 2002, Tempe, Arizona, USA.

BURGER, M., KLAR, B., MÜLLER, A. AND SCHINDLMAYR, G. (2004): A spot market model for pricing derivatives in electricity markets. Quantitative Finance, 4, 109-122.

CARTEA, A. AND FIGUEROA, M.G. (2005): Pricing in electricity markets: A mean reverting jump diffusion model with seasonality. Applied Mathematical Finance, 12, 313-335.

DENG, S.J. (1999): Stochastic models of energy commodity prices and their applications: mean reversion with jumps and spikes. POWER working paper, PWP-073, University of California Energy Institute, Berkeley.

ESCRIBANO, A., PEÑA, J. I., AND VILLAPLANA, P. (2002): Modelling Electricity Prices: International Evidence. Universidad Carlos III, Economics Series 08, Working Paper 02-27.

EYDELAND, A. AND GEMAN, H. (1998): Pricing Power Derivatives. Risk, October, 71-73.

FAMA, E. F., AND FRENCH, K. R. (1987): Commodity Futures Prices: Some Evidence on Forecast Power, Premiums, and the Theory of Storage. Journal of Business, 60, 55-74.

GEMAN, H. AND VASICEK, O. (2001): Plugging into electricity. Risk, August 2001, 93-97.

GOTO, M., AND KAROLYI, G. A. (2004): Understanding Electricity Price Volatility Within and Across Markets. Dice Center Working Paper No. 2004-12.

HALDRUP, N. AND NIELSEN, M. (2004): A regime switching long memory model for electricity prices, Working Paper 2004-02, Aarhus University.

KARAKATSANI, N.V. AND D.W. BUNN (2005): Diurnal reversals in electricity forward premia. Mimeo. London Business School. 
KELLERHALS, B.P. (2001): Pricing electricity forwards under stochastic volatility. Working paper, Department of Finance, College of Economics and Business Administration, Eberhard Karls University, Tubingen.

KOEKEBAKKER, S. AND OLLMAR F. (2005): Forward curve dynamics in the Nordic electricity market. Managerial Finance, 31, 73-94.

KOOPMAN, S.J., M. OOMS, AND M.A. CARNERO (2007): Periodic Seasonal RegARFIMA-GARCH Models for Daily Electriciy Spot Prices. Journal of the American Statistical Association, 102, 16-27.

LONGSTAFF, F. A., AND WANG A. W. (2004): Electricity Forward Prices: A HighFrequency Empirical Analysis. The Journal of Finance, 59, 1877-1900.

LUCIA, J.J. AND E.S. SCHWARTZ (2002): Electricity prices and power derivatives: Evidence from the Nordic Power Exchange. Review of Derivatives Research, 5, 5-50.

PIRRONG, C. AND JERMAKYAN, M. (2005): The price of power: the valuation of power and weather derivatives. Mimeo. University of Houston.

ROUTLEDGE, B.R., SEPPI D.J, AND SPATT C.S. (2001): The "spark spread": An equilibrium model of cross-commodity price relationship in electricity, Working paper GSIA WP\#1999-15, Carnegie Mellon University.

SHAWKY, H.A., MARATHE, A., AND BARRET, C.L. (2003): A First Look at the Empirical Relation Between Spot and Futures Electricity Prices in the United States. The Journal of Futures Markets, 23, 931-955.

TORRÓ, H. (2007): Forecasting weekly electricity prices at Nord Pool. Fondazione Eni Enrico Mattei, FEEM - Working Paper No. 88/2007.

VON DER FEHR, N.-H. M., AMUNDSEN, E.S., AND BERGMAN, L. (2005): The Nordic Market: Signs of Stress? The Energy Journal, European Energy Liberalisation Special Issue, 71-98.

WERON, R., SIMONSEN I. AND WILMAN P. (2004): Modelling highly volatile and seasonal markets: evidence from the Nord Pool electricity market. In H. Takayasu (editor), Procedings of the second Nekkei Econophysics symposium - Application of Econophysics 2002, 182-191, Springer.

WOLAK, F. (1999): Market design and price behavior in restructured electricity markets. An international comparison. In Ito, T. and Krueger, A. (ed.), Competition Policy in the Asia Pacific Region, EASE Volume 8, University of Chicago Press, 79-134. 